\title{
The Suitability of Mesozoic Limestone Aggregate for Possible use as Pavement Material in Harer-Dire Dawa Area.
}

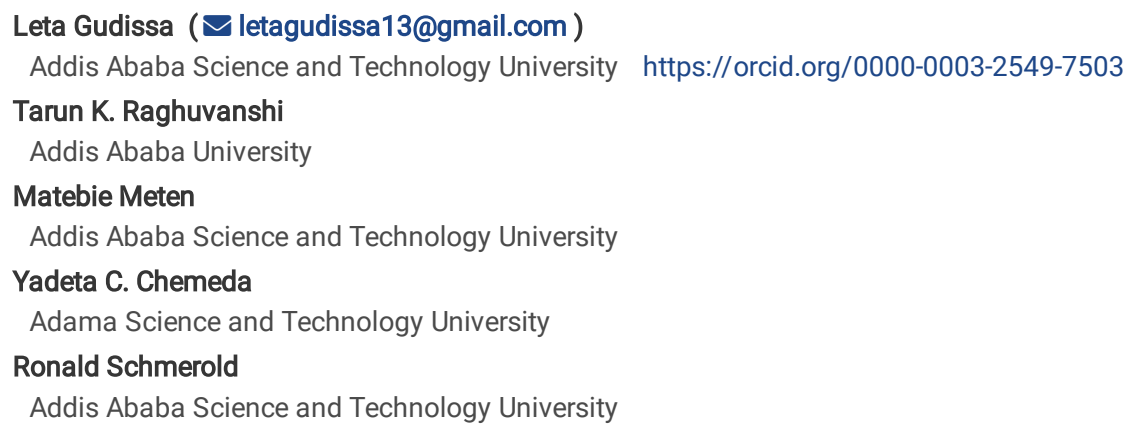




\section{Abstract}

Road construction requires a prime quality and a tremendous amount of aggregates, within which their quality is set by geological and geotechnical properties. Therefore, the Mesozoic limestone was studied in the vicinity of Harer and Dire Dawa towns, for the fundamental engineering assessments.

Thirty-seven Mesozoic limestone samples obtained from the area were subjected to petrographic and geotechnical analyses to work out the suitability of the rock as a road aggregate. Physical properties were investigated using ultrasonic pulse velocity (UPV), water absorption, $\mathrm{Na}_{2} \mathrm{So}_{4} \mathrm{Soundness}$, and specific gravity tests. However, the mechanical properties were determined using unconfined compressive strength (UCS), Aggregate crushing value (ACV), Aggregate Impact Value (AIV), and Los Angles Abrasion value (LAAV).

The study aimed to see if the limestone aggregate complies with the globally accepted standards by employing geotechnical laboratory analyses and petrographic examination.

The petrographic observations reveal the Mesozoic limestones of the area are dominantly composed of micrite, sparite, and bioclasts with subordinate intraclasts, ooids, Fe-oxides, and dolomites. Results of the physical properties show the rock has a mean UPV of $4859 \mathrm{~m} / \mathrm{s}$, a dry specific gravity of 2.64 , and very low water absorption ranging from $0.2-5.7 \%$, and $\mathrm{Na}_{2} \mathrm{So}_{4}$ soundness ranges from $1-14 \%$. Among the mechanical properties, UCS, AIV, ACV, and LAAV range from $20.5-180.5 \mathrm{Mpa}, 8-20 \%, 24-34 \%$, and $18.9-31.1 \%$, respectively.

Based on the aforementioned results, the limestones of the area are suitable for aggregate in road construction as they're complying with ERA, AASHTO, ASTM, and BS standards used for pavement works.

\section{Introduction}

Though limestones are hard, durable, and can be used as aggregate, the suitability of limestone for aggregate depends on several geological factors such as the type of minerals present, its strength, porosity, and durability (Adeyi, Mbagwu, Ndupu, \& Okeke, 2019). Other factors also include proportions of mineral grains; the type of contacts between the mineral grains; the layering of minerals; and the presence and interconnection of voids. These properties of crushed rock result from the origin and mineralogy of the source rock and its subsequent alteration and weathering. In general, older and more hardened limestone exhibits higher strengths and is suitable for road surfacing applications, as well as for use in the lower parts of the road pavement.

In road construction, more than $90 \%$ of asphalt pavements and $80 \%$ of rigid pavements are aggregates. Thus, understandably the properties of aggregates commonly affect the durability and performance of pavement projects; and it is essential to obtain the right type and best quality aggregates.

Huge sources of limestone rock which is about 750 meters thick and consists of predominantly fossiliferous yellow limestone are distributed randomly in the Mesozoic succession of the Harer area. Most people in the Harer area are using the limestone without checking the quality of the aggregates and it has shown different types of defects on the projects. In Ethiopia, limestone rock accounts for $10 \%$ of the total volume of all sedimentary rocks (Wondafrash, Sentayehu, and Geremew, 2009). In the area, identification of the limestone in particular (Wondafrash et al., 2009) and Mesozoic rocks, in general, was carried out by (Bosellini, Russo, \& Assefa, 2001).

In the area particularly, Haromaya watershed, hydrogeological investigation, and groundwater potential assessment were made by (Nata, Bheemalingeswara, and Abdulaziz, 2010). In the Dire Dawa area, the estimation of groundwater recharge and an assessment of the anthropogenic impact on groundwater resources were conducted by (Tilahun and Merkel, 2009) and (Abate, 2010) respectively. Additionally, comprehensive geological studies were carried out by the Geological Survey of Ethiopia (GSE), particularly, (Kibrie and Yirga, 2008 and Workineh, 2010) has produced geological maps of scale 1:250,000 for Dire Dawa and Harer sheets, where two sub-units of the limestone rocks were characterized.

Generally in Ethiopia, the characterization of rocks for their use in engineering applications is very rare except for very few works conducted by (Aragaw, 2008; Engidasew and Barbieri, 2014; Yirga, Weldearegay, and Abebe, 2017). However, the above investigations determine the suitability of aggregates for concrete works except (Engidasew and Barbieri, 2014) partly checked the application of Tarmaber basalt for pavement works. The suitability of volcanic rocks and their petrographic and physicomechanical behavior were evaluated for their use as construction materials in the city of Addis Ababa by (Tesfaye and Asmelash, 2016).

The Hakim Gara limestone occurring near Harer, Delga Chebsi limestone located $23 \mathrm{~km}$ northeast of Dire Dawa, Mesobo limestone near Mekele, and also the Jemma-Wonchit and Muger valley limestone of Northern Shewa are suitable as dimension stone and material for cement with resource within the order of innumerable tons. In Ethiopia, the Antalo limestones are mainly utilized for cement and dimension stone.

To the author's knowledge, no research was made and no information is out there on the geotechnical and petrographic properties of the Mesozoic limestone for its use in road construction. Therefore, full knowledge of the physical, mechanical, and petrographic behaviors of the limestone rock (Dweirj, Fraige, Alnawafleh, \& Titi, 2017) and determining the suitability of a rock for construction should be made before construction for the safe design of structures (Okogbue \& Aghamelu, 2013).

Most specifications and standards (AASHTO, ASTM, BS, and ERA), state the aggregate shall encompass "hard, strong, durable" particles. Weak aggregate isn't acceptable and will not be used. It's therefore important to use the only aggregate produced from strong limestone (good compressive strength). The properties are determined by simpler methods that dictate a load that can be absorbed before the failure of rock and commonly utilized to assess the standard of road stones. The principal laboratory tests include aggregate crushing tests, aggregate impact tests, aggregate abrasion resistance test, aggregate water absorption, specific gravity, and density test, compressive strength, and mineralogical characteristics of rock (Jethro, Shehu, \& Olaleye, 2014). 
Therefore, the massive quantities of Harer limestone, low cost, and also the lack of knowledge about their engineering properties, additionally to the expected future about to use the Harer limestone in pavement works, have encouraged the authors to hold out this research work.

Any geological material is used as construction aggregate as long as it satisfies the wants of the end-use specification (Adeyi et al., 2019). Aggregates used as road stones must possess high resistance to crushing and wishes to face up to the heavy load because of traffic wheel load, has to be tough enough to resist high impacts caused by the jumping of the steel tyred wheels and severe abrasion resistance, and it has to be sound enough to face up to the weathering action. It must even be impermeable, chemically inert, and possess a low coefficient of expansion. Therefore, this work emphasizes the detailed investigation and geomechanical characterization of the suitability of Harer limestone for pavement works. For this particular area; this research is the primary study and functions as a basis for future studies.

\section{The Study Area, Materials, And Methods}

\subsection{Location of The study area}

The study area is found in Eastern Ethiopia about $520 \mathrm{~km}$ far away from the national capital and extends $65 \mathrm{~km}$ from Dire Dawa town looking at the provision of limestone (Fig.1).

Dire Dawa will be accessed either by road, by air, or by train through Addis Ababa to Djibouti railway. But Harer town is accessible from the capital of Ethiopia through asphalt road. The topography of the area is hilly and rugged with 3378 and 976 masl max and min elevations respectively.

The temperature is hot throughout the year with minor differences due to the season and progressively increasing towards the north. The rainy seasons are from March to September, with a regular maximum rainfall from July to September.

\subsection{GEOLOGY OF the study area}

The regional geology of the study area consists of rock units starting from Precambrian basements up to recent sediments (Fig.2). The basements include high-grade gneisses, migmatites, fine to medium-grained amphibolite, and low-grade quartz-mica schist. Hill forming massive granite is exposed to underlying lower sandstone. Phyllite, greenstone, chert, serpentinites, and talc schist are exposed within the study area. The Mesozoic succession consists of the lower sandstone, carbonate, and upper sandstone (Bosellini et al., 2001).

Biostratigraphic consideration shows that the lower sandstone is correlated to Adigrat sandstone. However, the carbonates are correlated partly to Hamanlei and Uarandab sequences. In the end, the upper sandstone is an element of the Yesomma sequence (Balemwal, 1991). Volcanic basalts are exposed at the plateau, though not evenly distributed, and are generally exposed at isolated locations only. Further, the rift plain and parts of major valleys on the plateau contain alluvial sediments.

Reworked sediments occur on gentle slopes, and wide valley floors, and therefore the rift zones (Workineh, 2010). The local geology of the area is dominantly covered by the Antalo limestone (Fig.2). Gildessa limestone exposed in NE of Dire Dawa consists of massive, oolitic, coarse grainstone, parallel and cross lamination with marine coral fragments, bioturbated marly limestone with sparse fossils. It also consists of Dire Dawa Formation-black micritic limestone and marls rich in belemnites, ammonites, and gryphaea and marly limestone and marls rich in ammonites and mollusks. The Antalo limestone overlies the Lower Adigrat sandstone. The top parts of the limestone are weathered and in the Dire Dawa area, the limestone covers the escarpment zone (Ketema, 1982). It covers the up-thrown side of the block and the downthrown side is covered by the alluvium. In Hakimgara, large potential and easily accessible limestone deposits are found, forming hills and beds varying from tens of $(\mathrm{cm})$ to several $(\mathrm{m})$ in thickness (Walle, Zewde, \& Heldal, 2000). The well-sorted upper sandstone of the Mesozoic Era is exposed around Dire Dawa with intense weathering and erosion overlaying the antalo limestone.

The geologic structures within the limestone unit are joints, bedding, and solution cavities. They're developed along the bedding planes and along with the foremost tectonic directions. The limestone beds dip towards S and SW and strike E-W and NW-SE direction around Dire Dawa (Ketema, 1982). It always has a horizontal orientation (dips $<10^{\circ}$ ). Major joints run in the N-S direction along with the Ethiopian rift system while minor joint sets are perpendicular to the main joints. The joints have calcite and clay infillings with few $\mathrm{mm}$ wide openings; sometimes $20-30 \mathrm{~cm}$.

\section{3 Materials}

The previous preliminary suitability map (Fig.3 (a)) prepared for quarry sites in the area were used as a base map in the present investigation for rock sample collection. The highly and moderately suitable limestone sections were selected, from the previous suitability map by disregarding the unsuitable and low suitable limestone locations (Fig.3 (b)).

All engineering properties tests were carried out at Adama Science and Technology University with different aggregate testing apparatuses like Aggregate Impact Value (AIV) apparatus, sieves, flakiness, and elongation apparatus, Los Angles abrasion apparatus, water immersion bath, and compressive machines were used for the characterization purposes. A hydrometer was also used for specific gravity measurements of the $\mathrm{Na}_{2} \mathrm{So}_{4}$ solution during the preparation of 
the solution for the weatherability test. Additionally, thin section studies were done at Addis Ababa Science and Technology University with a petrographic plane polarizing microscope. Photographs of thin sections were also captured by a camera mounted petrographic microscope.

\subsection{Methods (Determining Engineering and Petrographic properties)}

Generally, the study encompasses the Geo-Engineering characterization of limestone for the evaluation of the limestone for pavement works. Particularly the investigation involves collecting rock block samples. Then cutting and preparation of cubic rock sample, rock crushing and aggregate sample preparation, geotechnical laboratory characterization, and evaluation of the aggregate samples. Last but not least is chemical characterization or determination of major oxide chemical composition, thin-section preparation, and petrographic description. The main points are presented within the following sections.

\subsubsection{Rock Block sample collection}

In the preceding study, among the whole of 101 slope sections investigated, thirty-seven sections were selected and identified as potentially suitable and planned for rock block sample collection. Accordingly, thirty-seven block samples were collected from highly and moderately suitable locations for geotechnical laboratory evaluation. Oversized block samples were collected and cut into many pieces so that the subsequent number of tests would be conducted upon it.

\subsubsection{Sample Preparation}

For the subsequent rock properties characterization, cubic samples were cut from each sample (Fig.4 (b)). A test specimen with dimensions of $70 \pm 5 \mathrm{~mm}$ was cut using a Red Band masonry saw (Fig.4 (a)). Red Band has an enclosed diamond blade, tilting table, and in-built pump for wet cutting. However, for the determination of most mechanical properties (except UCS), the rock blocks were crushed into aggregates. Coarse aggregate sample preparation and/or crushing were done manually by the laborer for all the samples.

\subsubsection{Physical properties Examination}

The limestone samples collected from selected sections were subject to index property and strength characterization. The geotechnical laboratory characterizations performed during this study include some principal tests to determine intact rock properties, particle shape, durability/or soundness, abradability, and particulate properties.

Particle shape characteristics, durability, and abradability were performed on crushed and graded; mostly coarse aggregates, and sometimes on fine aggregates, measuring fines generated under standard test conditions. Physical characteristics of the rock determined on cubic samples before loading under compressive machine are properties like UPV, dry density, specific gravity, water absorption, and porosity, etc.

2.4.3.1 UPV: The UPV measurements of compressional waves were carried out in line with (ASTM D2845, 2000) employing a high-energy pulser on the driving side and a 2-channel digital storage oscilloscope on the receiving side for recording time traveled. The UPV was determined by using the time-of-flight measurement technique at $82 \mathrm{kHz}$ frequency as the sample size allows good contact with this transducer. Energy transmission between the specimen and every transducer is also improved by employing a thin layer of a coupling medium like high vacuum grease, and by pressing the transducer against the specimen with a small seating force.

For a cube, the UPV was measured on three pairs of faces and three measurements were recorded for one pair of the face. Thus, there is a total of 9 records for one cube. Hence 37 samples multiplied by 9 records equals 333 records of UPV measurements were recorded.

2.4.3.2 Water absorption: The water absorption of the limestone cube was determined according to ISRM suggested methods. It had been determined by measuring the rise in weight of an oven-dried sample when immersed in water, for twenty-four hours with the surface water being removed. The water absorption of the sample (\%) is then calculated from the ratio of the difference between the weight of the saturated and surface dry sample (kg) and the weight of the oven-dry sample $(\mathrm{kg})$ to the weight of the oven-dry sample $(\mathrm{kg})$ multiplied by 100 . Regarding the number of data, a total of 148 records of water absorption were measured from all cubic samples.

2.4.3.3 Dry density: The dry density $\left(\mathrm{kg} / \mathrm{m}^{3}\right)$ of a cube was determined following the ISRM suggested method. It's obtained by the ratio of oven-dried mass ( $\mathrm{kg}$ ) of the cube to the bulk volume of the cube $\left(\mathrm{m}^{3}\right)$. The cubes were dried in an oven capable of maintaining a temperature of $105^{\circ} \mathrm{C}$ for twenty-four hours and weights of every cube were recorded using a balance accurate to $0.1 \mathrm{~g}$. The simplest direct method for determining the bulk volume of a consolidated sample with a good design geometric shape is to measure its dimensions. Thus, for the dry density measurement, bulk volumes were calculated from dimension measurements using the caliper technique. By using a vernier caliper, the dimensions of cubic samples were measured thrice at different locations for accurate computation of bulk volume, and averages of those three records were taken within the computation of the dry density. Thus, a total of 148 records of dry density were measured from all cubic samples.

2.4.3.4 Specific Gravity: The specific gravity was resolute using the buoyancy method following ISRM suggested methods. The bulk volume of regular or irregular specimens could also be calculated using the Archimedes principle, from the saturated-submerged sample weights. The standard procedure is to determine the volume of fluid displaced by the sample. The fluid volume that the sample displaces is often determined volumetrically. The displaced fluid should be prevented from penetrating the pore space of the sample. During this study, the fluid was prevented from penetrating the pore space of the sample by saturating the rock with the fluid into which it's to be immersed, and therefore the volume of the displaced fluid was determined volumetrically.

The saturated-submerged mass $\mathrm{M}_{\text {sub }}$ is decided to an accuracy of $0.1 \mathrm{~g}$ from the displaced volume of the saturated-submerged mass of the sample multiplied by the density of water (which is $1 \mathrm{Kg} / \mathrm{m}^{3}$ ). An oven-dried mass $\mathrm{M}_{\text {oven }}$, using an oven capable of maintaining a temperature of $105^{\circ} \mathrm{C}$ was also determined to 
an accuracy of $0.1 \mathrm{~g}$. The specific gravity is then obtained from the ratio of the mass of the oven-dried sample to the mass of an equal volume of displaced water.

2.4.3.5 Effective Porosity: The effective porosity is defined as the ratio of the volume of voids $\left(V_{v}\right)$ to bulk volume $\left(V_{\text {bulk }}\right)$ of the cubes multiplied by 100 , expressed in percentage. Therefore, effective porosity is the percentage of interconnected void space concerning the bulk volume.

2.4.3.6 Soundness: The soundness of the aggregate was performed using anhydrous $\mathrm{Na}_{2} \mathrm{So}_{4}$ chemical and also the test was performed following the test procedure in ASTM C88-99a, (1999). The test was performed by repeated immersion in saturated solutions of sodium sulfate followed by oven drying to partially or completely dehydrate the salt precipitated in permeable pore spaces. During this study, soundness tests were done on fine proportion for the very fact that a much higher amount of coarse aggregates are required if the coarse aggregate is to be used. Two determinations were performed for every sample and a complete of 74 data was recorded in aggregate soundness test.

2.4.3.7 Aggregate Particle Shape: Aggregate particle shape including flakiness and elongations were performed for all 37 aggregate samples. Two determinations were conducted for both flakiness and elongation tests. The flakiness and elongation indices were determined consistent with the procedures given by BS812-105.1, (1989) and BS 812-105.2, (1990).

\subsubsection{Mechanical properties Examination}

The mechanical properties laboratory examination includes rock sample and aggregate geotechnical evaluations like UCS, AIV, ACV, and LAAV, etc. Generally, Mechanical properties mean the toughness and hardness of the rock materials. The mechanical properties of rock aggregates, including the AIV and ACV, were measured consistent with the test procedures described by BS812-112, (1990) and BS 812-110, (1990), respectively. However, LAAV was performed following a test procedure described in ASTM C131-96, (1996). A minimum of three determinations was conducted for every test depending on the obtained results. Therefore, there are three records for one sample multiplied by a total of 37 samples equals 101 data of every parameter is available.

2.4.4.1 UCS: The UCS test is a mechanical test measuring the amount of compressive load a material can bear before fracturing. The test piece within the sort of a cube is compressed between the platens of a compression-testing machine by a gradually applied load. During this study, the UCS test was performed as per ASTM C170, (1999) and British Standard BS-EN-1926, (2006). For the UCS, four cubic samples were cut and made ready from each sample. Therefore, four cubes per sample multiplied by a complete of 37 equals to 148 cubic specimens were utilized to characterize the UCS.

2.4.4.2 AIV: For the AIV test, BS812-112, (1990), methods for the determination of the AIV were followed. The AIV gives a relative measure of the resistance of an aggregate to sudden shock or impact. An aggregate sample of about $700 \mathrm{~g}$ is taken and compacted in a standardized open steel cup. The specimen is then subjected to several standard impacts from dropping weight. An aggregate sample of $14 \mathrm{~mm}$ to $10 \mathrm{~mm}$ in size is subjected to discontinuous loading of 15 blows with a hammer. This action breaks the aggregate to a degree that relies on the impact resistance of the material. This degree is assessed by sieving the impacted specimen on a $2.36 \mathrm{~mm}$ sieve and is taken as the AIV. The \% of material passing relative to the initial weight gives the aggregate impact value.

For AIV, three repeated tests were conducted for statistical precision and therefore the average of two closely related values was considered as the final AIV. If the difference $\mathrm{b} / \mathrm{n}$ the two individual AIV isn't more than 0.15 times the mean of AIV; no need to conduct further additional tests to compute the median of the four tests.

2.4.4.3 ACV: The ACV was performed following BS 812-110, (1990) Determination of ACV gives a relative measure of the resistance of an aggregate to crushing under a gradually applied compressive load. The method applies to aggregates passing a $14.0 \mathrm{~mm}$ sieve and retained on a $10.0 \mathrm{~mm}$ test sieve. An aggregate sample of not more than $1.7 \mathrm{Kg}$ is taken and compacted in a standardized steel cylinder fitted with a freely moving plunger. The specimen is then subjected to a nonstop load at a homogenous rate up to $400 \mathrm{KN}$ transmitted through the plunger. This action breaks the aggregate to a degree that depends on the crushing resistance of the material. The entire crushed sample on the tray was sieved on a $2.36 \mathrm{~mm}$ sieve until no further significant amount passes. The fraction passing was weighed and recorded. Two additional repetitions of the test would be conducted for statistical precision and if the mean is less than 1.8 times the difference of the two values, the average of two closely related values was considered as the final ACV. However if 1.8 times the difference between the two values is larger than the average value, yet one more additional test is conducted and the median was considered as ACV.

2.4.4.4 LAAV: The LAAV was conducted according to the test procedures described by ASTM C131-96, (1996). In the LAAV test, the aggregate of specified grading is placed in a cylindrical drum, mounted horizontally. A charge of steel balls is added and therefore the drum is rotated a specified number of revolutions. The tumbling and dropping of the aggregate and also the balls lead to abrasion and attrition of the aggregate.

\subsubsection{X-Ray Fluorescence (XRF)- Chemical Composition}

Generally, thirty-seven powdered rock samples were submitted to Dire Dawa National cement factory for XRF-chemical composition determination of major oxides. All the samples were placed into groups with similar mineralogical and textural characteristics like roundness, matrix, cement type, and porosity.

XRF is the commonest chemical technique that helps to spot the main oxides of samples with a differing composition such as silicates, carbonates, sulfates, and phosphates from below $0.01 \%$ to $100 \%$. The analysis is rapid and non-destructive (Jamaluddin, Darwis \& Massinai, 2018) as well as widely used for elemental and chemical analysis, particularly in the investigation of geologic construction materials. The major oxides test was carried out on as little as $0.5 \mathrm{~g}$ of material. The sample material was analyzed as a pressed powder fused into a glass disk using a suitable flux, such as lithium tetraborate (Jamaluddin et al, 2018). Using fused samples allows an evenly dispersed primary solid solution, which enables a good range of matrix compositions to be accurately, determined through the normalization of particle size and inter-element (matrix) effects. 
The elements within the sample can therefore be identified by their spectral wavelengths for chemical analysis and therefore the intensity of the emitted spectral lines enables quantitative chemical analysis.

\subsubsection{Petrographic Examination}

For petrographic examinations, thirty-seven hard rock samples were used to investigate the mineralogical variation of limestones. The thin sections were cut and polished in the central laboratory of GSE.

For mineralogical characteristics, the modal analysis of thin sections was used. It's the method of determining the petrography of rocks by counting the various minerals thereby determining the mineralogical composition and therefore the percentage of crystal formation of varied minerals present in the samples of each rock type (Jethro et al., 2014). According to Jethro et al., (2014), "Percentage Mineral Composition" can be calculated using (eq.1).

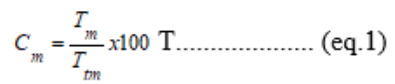

Where, $C_{m}=$ Percentage mineral composition (\%); $T_{m}=$ Total number of count for a mineral, and $T_{t m}=$ Total number of count for the entire mineral.

Thin-section observation allows for a description to be made of the petrographic aspects and classification of the stones (Brilli, Giustini, \& Kadıoglu, 2018). Accordingly, each thin section was viewed under a petrographic plane polarizing microscope. They are prepared for the study of the relative abundance of the sparite and micrite cement, fossils, and diagenetic features.

The classification scheme of Dunham (1962) and Folk (1962) have been applied for the carbonate rock naming. Textures, fabrics, crystal boundary shapes and grain size features were observed, providing descriptive parameters for the characterization of the kinds of carbonate (Dunham, 1962; Wright, 1992; Brilli et al., 2018).

\section{Results And Discussion}

Properties such as ultrasonic pulse velocity, dry density, specific gravity, effective porosity, water absorption, and volume of voids as well as mechanical properties like compressive strength and other aggregate tests of limestone play a vital role in its geotechnical characteristics (Alqahtani, Seif, \& Sedek, 2013).

According to ERA-STS-2002, it is recommended to reject if the ACV (\%) exceeds a value of $29 \%$ for road construction work. Therefore, based on the result shown in Table 1; the ACV of the limestone aggregate from samples \#47 and \#86 indicated a bit above the limit of ERA-STS.

The results of UPV for the limestone samples from the study area range from $2940 \mathrm{~m} / \mathrm{s}$ to $5370 \mathrm{~m} / \mathrm{s}$ while the highest values were recorded for sample \#37 and the least values were from sample \# 86 and with an average value of $4859 \mathrm{~m} / \mathrm{s}$ (Table 1). The values were in good agreement with the compressive strength, degree of weathering, and rifting of samples.

Table 1. Results for different engineering properties of limestone 


\begin{tabular}{|c|c|c|c|c|c|c|c|c|c|c|c|c|c|c|c|}
\hline Rock Type & Sample & $\begin{array}{l}F_{1} \\
(\%)\end{array}$ & $\begin{array}{l}E_{1} \\
(\%)\end{array}$ & $\begin{array}{l}\mathrm{W}_{\mathrm{a}} \\
(\%)\end{array}$ & $\begin{array}{l}E_{p} \\
(\%)\end{array}$ & $\begin{array}{l}D_{d} \\
\left(k g / m^{3}\right)\end{array}$ & $\begin{array}{l}S_{d} \\
\left(k g / m^{3}\right)\end{array}$ & $\begin{array}{l}\mathrm{U}_{\mathrm{w}} \\
\left(\mathrm{kN} / \mathrm{m}^{3}\right)\end{array}$ & $S_{g}$ & $\mathrm{U}_{\mathrm{pv}}(\mathrm{m} / \mathrm{s})$ & $\begin{array}{l}\text { UCS } \\
\text { (Mpa) }\end{array}$ & $\begin{array}{l}\mathrm{S}_{\mathrm{o}} \\
\mathrm{Na}_{2} \mathrm{So}_{4} \\
(\%)\end{array}$ & $\begin{array}{l}\text { AIV } \\
(\%)\end{array}$ & $\begin{array}{l}\text { ACV } \\
(\%)\end{array}$ & TFV( \\
\hline \multirow{4}{*}{$\begin{array}{l}\text { Siliceous } \\
\text { Calcareous } \\
\text { Dolomite }\end{array}$} & 24 & 25 & 13 & 1.57 & 3.86 & 2524.1 & 2587.6 & 24.8 & 2.55 & 5020 & 116.5 & 3.6 & 11.7 & 26.3 & 157.1 \\
\hline & 63 & 26 & 7 & 0.36 & 0.96 & 2697.5 & 2709.9 & 26.5 & 2.70 & 4650 & 90.0 & 1.0 & 13.0 & 27.3 & $137 . \varepsilon$ \\
\hline & 90 & 21 & 6 & 1.88 & 4.97 & 2616.8 & 2649.3 & 25.7 & 2.60 & 4730 & 102.5 & 6.1 & 13.1 & 26.6 & 130.4 \\
\hline & 84 & 21 & 5 & 1.49 & 3.88 & 2618.7 & 2664.0 & 25.7 & 2.63 & 4050 & 82.5 & 8.1 & 13.6 & 30.4 & 120.1 \\
\hline \multirow{4}{*}{$\begin{array}{l}\text { Dolomatized } \\
\text { bio intra } \\
\text { sparitic } \\
\text { Limestone }\end{array}$} & 2 & 19 & 14 & 0.35 & 0.90 & 2627.6 & 2654.4 & 25.8 & 2.65 & 5290 & 100.0 & 7.2 & 12.1 & 28.3 & $143 .($ \\
\hline & 48 & 19 & 5 & 3.01 & 7.56 & 2527.5 & 2609.1 & 24.8 & 2.53 & 4240 & 76.5 & 5.2 & 15.8 & 28.0 & 130. \\
\hline & 60 & 15 & 10 & 0.54 & 1.37 & 2626.8 & 2700.7 & 25.8 & 2.69 & 4700 & 110.5 & 5.7 & 9.4 & 28.9 & 168. \\
\hline & 10 & 32 & 9 & 0.28 & 0.75 & 2672.9 & 2684.1 & 26.2 & 2.68 & 5020 & 82.0 & 2.7 & 12.7 & 29.6 & 131.i \\
\hline \multirow{6}{*}{$\begin{array}{l}\text { Dolomatized } \\
\text { bio intra } \\
\text { micritic } \\
\text { Limestone }\end{array}$} & 49 & 21 & 13 & 0.17 & 0.46 & 2705.1 & 2717.1 & 26.5 & 2.71 & 5130 & 99.0 & 1.0 & 10.7 & 31.0 & 152.8 \\
\hline & 50 & 26 & 14 & 2.87 & 7.42 & 2553.8 & 2589.2 & 25.1 & 2.52 & 3920 & 115.5 & 3.1 & 10.8 & 28.3 & 160. \\
\hline & 4 & 26 & 19 & 0.17 & 0.44 & 2636.9 & 2648.9 & 25.9 & 2.64 & 5300 & 72.0 & 1.6 & 13.0 & 30.0 & $130 . c$ \\
\hline & 77 & 24 & 9 & 0.32 & 0.87 & 2669.1 & 2657.6 & 26.2 & 2.65 & 4730 & 55.5 & 2.4 & 14.5 & 31.1 & 110.1 \\
\hline & 71 & 17 & 9 & 3.75 & 8.99 & 2452.1 & 2599.9 & 24.1 & 2.51 & 3960 & 60.5 & 6.9 & 15.2 & 29.4 & 109.؟ \\
\hline & 42 & 21 & 8 & 0.34 & 0.92 & 2738.4 & 2753.8 & 26.9 & 2.75 & 5330 & 60.5 & 1.4 & 15.1 & 30.5 & 107.4 \\
\hline \multirow{4}{*}{$\begin{array}{l}\text { Dolomatized } \\
\text { bio oo spary } \\
\text { Limestone }\end{array}$} & 47 & 24 & 8 & 0.29 & 0.83 & 2742.6 & 2789.1 & 26.9 & 2.78 & 4970 & 41.0 & 6.2 & 15.1 & 34.1 & 97.0 \\
\hline & 72 & 30 & 10 & 0.32 & 0.83 & 2645.6 & 2697.3 & 26.0 & 2.69 & 4820 & 76.5 & 3.2 & 12.1 & 30.4 & 134.4 \\
\hline & 99 & 29 & 6 & 1.71 & 4.23 & 2607.1 & 2785.6 & 25.6 & 2.74 & 5110 & 100.0 & 3.0 & 13.1 & 27.6 & 139.6 \\
\hline & 34 & 26 & 7 & 0.41 & 1.12 & 2683.1 & 2672.2 & 5.0 & 2.66 & 4930 & 91.5 & 2.8 & 13.8 & 27.5 & $130 . c$ \\
\hline \multirow{6}{*}{$\begin{array}{l}\text { Siliceous bio } \\
\text { pel micritic } \\
\text { Limestone }\end{array}$} & 58 & 30 & 4 & 0.45 & 1.26 & 2762.1 & 2768.8 & 27.1 & 2.76 & 5050 & 54.0 & 2.0 & 15.2 & 30.2 & $108 . \mathrm{c}$ \\
\hline & 70 & 22 & 9 & 0.27 & 0.69 & 2643.2 & 2694.6 & 25.9 & 2.69 & 5120 & 78.0 & 3.0 & 12.1 & 29.8 & 137.1 \\
\hline & 7 & 32 & 9 & 0.33 & 0.88 & 2689.1 & 2725.2 & 26.4 & 2.72 & 5240 & 68.0 & 1.4 & 13.5 & 30.3 & $120 . i$ \\
\hline & 37 & 23 & 12 & 0.22 & 0.61 & 2698.7 & 2686.8 & 26.5 & 2.68 & 5370 & 73.0 & 2.4 & 12.3 & 30.1 & 137. \\
\hline & 29 & 11 & 19 & 0.38 & 1.02 & 2639.8 & 2603.8 & 25.9 & 2.59 & 5290 & 87.0 & 4.7 & 15.3 & 27.5 & 116. \\
\hline & 67 & 22 & 13 & 0.28 & 0.68 & 2564.6 & 2596.2 & 25.2 & 2.59 & 5290 & 108.0 & 2.1 & 12.6 & 26.4 & $154 . i$ \\
\hline \multirow{5}{*}{$\begin{array}{l}\text { Bio intra } \\
\text { spary } \\
\text { Limestone }\end{array}$} & 59 & 18 & 6 & 1.53 & 3.80 & 2476.7 & 2499.6 & 24.3 & 2.46 & 4740 & 110.0 & 8.9 & 13.8 & 27.5 & $130 . c$ \\
\hline & 19 & 28 & 6 & 0.40 & 1.09 & 2712.6 & 2686.2 & 26.6 & 2.68 & 5120 & 74.0 & 0.6 & 13.4 & 30.2 & 141.4 \\
\hline & 17 & 13 & 7 & 0.90 & 2.37 & 2644.4 & 2671.6 & 25.9 & 2.65 & 5280 & 39.0 & 3.5 & 16.7 & 31.7 & 94.2 \\
\hline & 46 & 18 & 5 & 0.43 & 1.16 & 2715.2 & 2727.9 & 26.6 & 2.72 & 5040 & 145.0 & 1.3 & 8.4 & 27.5 & $212 . \varepsilon$ \\
\hline & 16 & 35 & 8 & 1.65 & 4.11 & 2538.6 & 2636.7 & 24.9 & 2.60 & 4880 & 68.0 & 3.0 & 13.2 & 30.3 & 139.5 \\
\hline \multirow{8}{*}{$\begin{array}{l}\text { Bio intra } \\
\text { micritic } \\
\text { Limestone }\end{array}$} & 13 & 22 & 7 & 1.71 & 4.41 & 2550.8 & 2567.5 & 25.0 & 2.53 & 4590 & 48.5 & 7.4 & 15.1 & 32.2 & 102.1 \\
\hline & 82 & 38 & 12 & 1.52 & 3.83 & 2604.2 & 2041.3 & 19.2 & 2.68 & 4730 & 85.5 & 2.4 & 11.3 & 31.3 & 140.5 \\
\hline & 78 & 27 & 11 & 0.33 & 0.86 & 2625.0 & 2670.8 & 25.8 & 2.66 & 4990 & 87.0 & 1.5 & 12.9 & 28.3 & $133 . \varepsilon$ \\
\hline & 40 & 37 & 18 & 0.45 & 1.20 & 2741.4 & 2821.1 & 26.9 & 2.81 & 5060 & 61.5 & 1.5 & 14.6 & 30.6 & $110 . t$ \\
\hline & 25 & 25 & 13 & 0.47 & 1.28 & 2754.6 & 2765.0 & 27.0 & 2.66 & 5170 & 122.5 & 2.7 & 11.1 & 27.2 & $164 . i$ \\
\hline & 28 & 31 & 13 & 0.24 & 0.66 & 2604.2 & 2041.3 & 20.0 & 2.71 & 5140 & 180.5 & 2.6 & 9.7 & 24.5 & 177.1 \\
\hline & 32 & 29 & 10 & 0.79 & 2.02 & 2585.9 & 2624.9 & 25.4 & 2.61 & 4850 & 72.0 & 3.3 & 12.4 & 31.5 & $127 . \varepsilon$ \\
\hline & 86 & 21 & 6 & 5.73 & 13.75 & 2366.5 & 2467.9 & 23.2 & 2.34 & 2940 & 20.5 & 14.2 & 19.9 & 33.3 & 75.7 \\
\hline Minimum & & 11 & 4 & 0.17 & 0.44 & 2366.5 & 2041.3 & 19.2 & 2.34 & 2940 & 20.5 & 0.6 & 8.4 & 24.5 & 75.7 \\
\hline Maximum & & 38 & 19 & 5.73 & 13.75 & 2761.1 & 2821.1 & 27.1 & 2.81 & 5370 & 180.5 & 14.2 & 19.9 & 34.1 & $212 . \varepsilon$ \\
\hline Mean & & 24 & 10 & 1.02 & 2.60 & 2628.7 & 2634.2 & 24.9 & 2.64 & 4859 & 84.2 & 3.8 & 13.2 & 29.3 & $132 . \varepsilon$ \\
\hline $\begin{array}{l}\text { Standard } \\
\text { deviation }\end{array}$ & & 6.3 & 3.9 & 1.2 & 2.9 & 88.9 & 162.4 & 3.8 & 0.1 & 494.9 & 30.4 & 2.8 & 2.2 & 2.1 & 25.6 \\
\hline
\end{tabular}


Note: ACV: Aggregate Crushing Value; $D_{d}$ : Dry Density; $E_{1}$ : Elongation Index; $E_{p}$ : Effective porosity; $F_{1}$ : Flakiness Index; LAAV: Los Angles Abrasion Value; $S_{d}$ : Saturated Density; $\mathrm{S}_{\mathrm{g}}$ : Specific Gravity; $\mathrm{S}_{\mathrm{o}}$ : Soundness; TPFV: Ten percent fine Value; $\mathrm{U}_{\mathrm{PV}}$ : Ultrasonic Pulse Velocity; UCS: Uniaxial compressive strength; $\mathrm{U}_{\mathrm{w}}$ Unit Weight; Vv: Volume of voids; $\mathrm{W}_{\mathrm{a}}$ : Water Absorption

Regarding water absorption values, the cube samples have water absorption values ranging from $0.2-5.7 \%$ with an average value of $1.02 \%$ (Table 1 ). However, the minimum value of the water absorption was determined for the dolomitized biointramicritic limestone (Sample \#4 and 49 ) which is dense and fine-grained while the maximum water absorption was recorded from biointramicritic limestone (\#86).

The water absorption and specific gravity of aggregates are important properties that are required for the design of concrete and bituminous mixes. The amount of water that an aggregate can absorb tends to be a wonderful indicator of the strength or weakness of the aggregate. Strong aggregates will have an awfully low absorption below $1 \%$. An aggregate with high moisture absorption isn't likely to be a suitable road-building material. Generally, less absorptive aggregates often tend to be more resistant to mechanical forces and wetting. The appropriate limit of water absorption generally ranges from 1-5\%. However, lightweight aggregates have higher water absorption values usually from $5-20 \%$. Water absorption values range from 0.1 to about 2.0 percent for aggregates particularly utilized in road surfacing. Thus, all the samples within the current study satisfy this requirement except sample \#86.

The specific gravity of the limestone samples ranges from 2.34-2.81 and the average specific gravity for the limestone in the study area is 2.64 . The specific gravity of aggregates normally utilized in pavement construction ranges from about 2.5-2.9. The minimum value of 2.34 was obtained for sample ML 86 (biointramicritic limestone) and the maximum value (2.81) was obtained for sample \#40 which is also biointramicritic limestone.

The dry densities of the samples vary from $2366.5-2762.1\left(\mathrm{~kg} / \mathrm{m}^{3}\right)$ and the average value of dry density is $2634.2\left(\mathrm{~kg} / \mathrm{m}^{3}\right)$ for the limestone in the study area. The lowest value is from sample ML 86 (biointramicritic limestone) and the highest one is from sample ML 58 (siliceous biopelmicritic limestone). There is no significant variability among the values concerning the dry density. Although the strength of high-density limestone (sample ML 58 ) is relatively high, the natural discontinuities made the rock mass weak.

Effective porosity is defined as the ratio of the volume of voids $\left(V_{v}\right)$ to bulk volume $\left(V_{\text {bulk }}\right)$ of the cubes multiplied by 100 , expressed in percentage (eq.2).

EffectivePorosity (\%) $=\left(\frac{V_{v}}{V_{b u l k}} * 100\right)$.

(eq.2)

The limestone of the study area was evaluated and the minimum and maximum effective porosity is $0.44 \%$ for sample no \#4 from dolomitized biointramicritic Limestone and $13.75 \%$ for sample no \#86 from biointramicritic Limestone respectively.

About $89 \%$ of the total studied samples have effective porosity not exceeding $5 \%$. It is widely understood that diagenetic processes play a key role in controlling porosity and permeability within limestone (Alqahtani et al., 2013). Petrographical analyses of the remaining samples indicate that the diagenetic processes increase the total porosity of the studied limestone.

Table 2. Permissible Limits of AIV, ACV, LAAV, TPFV, FI, and Soundness $\left(\mathrm{Na}_{2} \mathrm{So}_{4}\right)$ for pavement applications (Ethiopian Roads Authority Standard Technical Specification (ERA-STS), 2002) 


\begin{tabular}{|c|c|c|}
\hline Engineering Parameters & Purpose & Standards Applied \\
\hline AIV (max.) 45\% & Crushed stone unbound road base course & BS 882:1992 \\
\hline AIV (max.) 30\% & $\begin{array}{l}\text { Bituminous bound surfacing or wearing } \\
\text { course }\end{array}$ & BS 882:1992 \\
\hline ACV (max.) 29\% & Crushed stone unbound road base course & ERA-STS-2002 \\
\hline ACV (max.) 25\% & $\begin{array}{l}\text { Bituminous bound surfacing or wearing } \\
\text { course }\end{array}$ & ERA-Pavement Design Manual Volume I-2002 \\
\hline LAAV (Max) 35\% & Crushed stone unbound road base course & ERA-STS-2002 \\
\hline LAAV (Max) 30\% & $\begin{array}{l}\text { Bituminous bound surfacing or wearing } \\
\text { course }\end{array}$ & ERA STS 2013 Clouse 6303[b] (ii) \\
\hline TPFV (Min) 110\% & Crushed stone unbound road base course & ERA STS 2013 Clouse 8404[d] Table 5204/2 \\
\hline TPFV (Min) 100 & $\begin{array}{l}\text { Bituminous bound surfacing or wearing } \\
\text { course }\end{array}$ & $\begin{array}{l}\text { ERA STS } 2013 \text { Clouse 6303[b] (ii) Table 6303/9, } \\
6303 / 12\end{array}$ \\
\hline $\mathrm{FI}(\mathrm{Max}) 30 \%$ & Crushed stone unbound road base course & ERA STS 2013 Clouse 5204[b] \\
\hline $\mathrm{FI}(\operatorname{Max}) 20 \%$ & $\begin{array}{l}\text { Bituminous bound surfacing or wearing } \\
\text { course }\end{array}$ & PD 6682-1:2003 Recommend FI 20 of BS EN 12620 \\
\hline $\begin{array}{l}\text { Soundness }\left(\mathrm{Na}_{2} \mathrm{SO}_{4}\right)(\mathrm{Max}) 10 \% \text { for fine } \\
\text { aggregate }\end{array}$ & Crushed stone unbound road base course & $\begin{array}{l}\text { ERA STS } 2013 \text { Clouse } 8402 \text { [C] (i) and AASHTO M80, } \\
\text { Table } 2\end{array}$ \\
\hline $\begin{array}{l}\text { Soundness }\left(\mathrm{Na}_{2} \mathrm{SO}_{4}\right)(\mathrm{Max}) 10 \% \text { for fine } \\
\text { aggregate }\end{array}$ & $\begin{array}{l}\text { Bituminous bound surfacing or wearing } \\
\text { course }\end{array}$ & ERA STS 2013 Clouse 6303[b] (ii) \\
\hline
\end{tabular}

Generally, better aggregate surface texture and higher angularity lead to a good aggregate-cement bond and good particle interlock, both of which help in achieving good compressive strength properties. However, flakey aggregate has less strength than cubical aggregate and doesn't create the dense matrix that well-graded cubic aggregate can do, and it'll provide less texture when used in the surface dressing. E.g. Granular sub-base with a high proportion of flakey aggregate tends to segregate and be difficult to compact. Moreover, Flakey chippings do not create the surface texture that a cubic or angular chipping can produce. Flaky particles are more easily stripped from bitumen seals. In flakiness study, it involves investigating the lithological causes, as distinct from the crushing induced, causes of flakiness. The flakiness index of the limestone aggregate in the study area ranges from $11-38 \%$, and the elongation index ranges from 4-19\%. The maximum and minimum flakiness index values were from sample \#82 and \#29, respectively. However, the maximum for the elongation index was from samples \#4 and \#29 whereas the minimum values were from sample \#58. In this study, fortunately, most samples satisfy the requirements for road base course (Table 2).

The soundness test is meant to review the resistance of aggregates to weathering action, by conducting accelerated weathering test cycles. Porous aggregates subjected to $\mathrm{Na}_{2} \mathrm{SO}_{4}$ solution are likely to disintegrate prematurely. To ascertain the soundness of such aggregates, aggregates of specified sizes are subjected to an accelerated cycle of alternate wetting utilizing a saturated solution of $\mathrm{Na}_{2} \mathrm{SO}_{4}$. The minimum and maximum percentage of losses of $\mathrm{Na}_{2} \mathrm{So}_{4}$ soundness are $1 \%$ and $14 \%$ respectively. The minimum values were exhibited by samples (such as \#63, \#49, \#42, \#7, \#19, and \#46) (Table 1). The maximum values were from sample \# 86 and the average values for the Harer-Dire Dawa limestone are 4\%. According to ERA STS 2013, the loss in weight should not exceed 10 percent for fine aggregate when tested with sodium sulfate. Thus, fortunately, only sample number 86 exceeds the maximum limit, and therefore, most samples are suitable concerning soundness. A relatively lower limit value of $\mathrm{Na}_{2} \mathrm{SO}_{4}$ soundness is set for fine aggregates than coarse aggregates; because there is an interconnection between soundness or weatherability and particle sizes or surface area. The weatherability or soundness increases as particle size decreases or as surface area increases.

Results of the compressive strength value of the limestone samples range from a minimum value of $20.5 \mathrm{MPa}$ to a maximum value of $180.5 \mathrm{Mpa}$, the limestone in the study area has a mean value of $84 \mathrm{Mpa}$, thus mainly classified into strong rock according to (Singh \& Goel, 2011) and as medium-strong to very strong rocks. It is found that about $89 \%$ of the tested samples have a compressive strength of more than $50 \mathrm{MPa}$. Hence, it is safe to say that the compressive strength values of the samples are more than 50Mpa with 95\% confidence. The highest compressive strength was recorded for samples ML28 which is from biointramicritic Limestone and the lowest value is for sample ML86 from the same group. The average compressive strength results of the limestones in the study area are satisfactory and accepted results that satisfy the utilization of such rocks as crushed stones for road construction purposes.

The maximum and minimum values for AIV were $20 \%$ and $8 \%$, respectively. The maximum value was obtained from sample \# 86 and the minimum AIV value is obtained from sample \#46. The average value for Harer-Dire Dawa limestone is $13.2 \%$. AlV is used as a measure of resistance to sudden impact. Low numerical value means a resistant rock (eq.3).

$A I V(\%)=\left(\frac{\text { Weight of fines passing } 2.36 \text { sieve }}{\text { Original Weight of Sample }} 100\right)$.

AIV's, below 10 are considered as strong, and AIV's above 35 would normally be considered as too weak to be used on road surfaces. Aggregates to be used for wearing course, the AIV shouldn't exceed $30 \%$. For water-bound macadam base courses, the maximum permissible value defined by BS $882: 1992$ is $45 \%$. Thus, as far as AIV is concerned, in the current study, all samples satisfy the requirements for road construction (Fig 6 (a)).

Page 9/21 
On the other hand, the aggregate crushing value is a value that indicates the ability of an aggregate to resist crushing. The lower the value the stronger the aggregate is i.e. the greater its ability to resist crushing. A value below 10 signifies an exceptionally strong aggregate while above 35 would normally be considered as weak aggregates. Therefore, all the samples in the current study exhibit ACV between 10-35 (Table 1) indicating that they are strong aggregates. The degree of resistance is assessed from fines particles passing BS sieve $2.36 \mathrm{~mm}$ which are calculated as the percentage of initial weight. The percentage resulting is taken as a measure of the aggregate crushing value (eq.4).

$A C V(\%)=\left(\frac{\text { Weight of fines passing } 2.36 \text { sieve }}{\text { Original Weight of Sample }} 100\right)$.

The maximum and minimum for the aggregate crushing value (ACV) ranges from $34 \%$ to $24 \%$ while the maximum ACV value was exhibited by sample no 47 from dolomitized biooospary Limestone and minimum value by sample \#28 from biointramicritic Limestone. The mean value of ACV for Harer-Dire Dawa limestone is $29 \%$. According to (Ethiopian Roads Authority Standard Technical Specification (ERA-STS), 2002), the ACV should preferably be less than $25 \%$ and in any case less than $29 \%$ for road base course (Table 2, Fig 6 (b)).

The principle of the LAAV test is to find the percentage wear due to relative rubbing action between the aggregate and steel balls used as an abrasive charge. A maximum value of $35 \%$ and $30 \%$ is allowed for road base course and wearing course in Ethiopian conditions (ERA-STS-2002 and ERA-STS-2013). The maximum and minimum LAAV were $31.1 \%$ and $18.9 \%$ respectively. The maximum value was from sample \#86 and the minimum value was from sample \#28. Both minimum and maximum values were obtained from the same group of limestone which is biointramicritic Limestone indicating the variation in the result is due to micro-structures and alteration or weathering.

For road sub-base applications, the LAAV shall not exceed 45\% when determined following the requirements of (AASHTO T 96-94, 1994). Consequently, in the current study, all samples except sample \#86 satisfy the requirement for road sub-base, base course, and bituminous bound surfacing or wearing course (30\%), (Table 2 and Fig 6 (c)). Therefore, the aggregate of these limestones will not wear away; abrade too quickly particularly when present in wearing courses and surface treatments.

The results of the XRF analysis show $\left(\mathrm{Fe}_{2} \mathrm{O}_{3}, \mathrm{MgO}, \mathrm{CaO}\right.$, and $\left.\mathrm{SiO}_{2}\right)$ major oxides that dominate the rock sample in the study area. The XRF analysis of samples from Harer-Dire Dawa revealed an average value of $\mathrm{CaO}$ of $49.23 \%$ with average levels of $\mathrm{MgO} 1.71 \%$ (Table 3 ). Calcium oxide (CaO) is the most dominant oxides in all samples of the study area but Silica $\left(\mathrm{SiO}_{2}\right)$ is the next dominant.

The microscopic investigations of thirty-seven samples of the Harer limestone indicated the presence of three main components; allochems (grains), matrix (mostly micritic), and cement (spray calcite). The allochems are mainly composed of fossils. These skeletal components are embedded in micritic fine groundmass or cemented by sparitic cement.

Diagenesis processes (compaction, dissolution, cementation, recrystallization, and dolomitization) are of special importance when studying carbonate sediments because these processes modify the texture, structure, and composition of the original sediments (Alqahtani et al., 2013). Consequently, the modifications may greatly affect their mechanical properties.

The relatively higher porosity of the samples may be related to its higher bio-clastic contents. This is indicated in (Fig.7) as the percentages of bio-clastic contents increases, the porosity also increases.

The geological classification of the different limestone, in this case, is mainly based on carbonate grains. The grains include skeletal and non-skeletal grains. The skeletal grains are bioclast or fossils which were transported, broken, abraded, and still completely preserved shells such as bi-values. However, nonskeletal grains are peloids, ooids, and various coated grains. Plates 1-8 and Fig.5 (a-g) show the results of the photomicrographs and the modal composition of the various samples examined in this work. In the present study, micrite, sparite, intraclasts, ooids, fossils, peloids, clastic quartz, dolomite, and Fe-oxides are the main minerals present (Fig.5 (a-g)). From the results, it can be concluded that ML-29 has the highest percentage composition of micrite content of $60 \%$ as compared to sample \#17 which is $9 \%$. In the thin section of ML-29, micrite appears dark, featureless, and microcrystalline (plate 1). The matrix is a finegrained, homogeneous texture, bio-clastic micrite. The slide of sample \#17 contains a prominent pressure solution seam with spacing in mm laying in the horizontal direction with large stylolite. Moreover, brownish Fe-oxides staining remains in the pressure solution seam. Pressure solution can increase the dissolution of calcite and is believed to be a significant source for the formation of porosity (Erik, 2010). On the other hand, pressure solution may create conduits for fluids and open migration paths leading to low strength value of the sample. Thus ML-29 has the highest strength value as compared to sample \#17. Sample \#ML-24 and CL-90 contain the highest percentage of clastic quartz (plate 3 ) which adds to the high strength value. In these samples, (sample ML-24 and CL-90), the whole matrix is dolomite sparite, and fossils are converted to sparite. The development of a good rhombohedral structure is a typical form of dolomites and uncommon in calcites. Therefore, all these add to the high strength value. On contrary, samples \# 84 and 72 contain the least clastic quartz and this adds to the lowest strength values as shown in the modal composition. The slide of sample \#72, contain coated grains formed by a series of concentric layers of calcite surrounding a quartz nucleus. Oolites form quartz in the core and concentric calcites (plate 4). The calcite cement in the interparticle pores appears white and the spaces between ooids are filled by sparite. In this oolitic limestone, the Oolitic grains form rounded or spherical morphometry with a smooth surface or small scale roughness and the individual grains are supported by the sparitic matrix. The Mud-support (matrix support) fabric is indicated by grains 'floating' in lime mud (plate 4). Thus, these also contribute to the lowest strength values. The sparite of this sample is both calcite and dolomite.

The fine to medium texture of sample \# ML-29 also confirmed the hardness of the rock as indicated in the results of aggregate mechanical properties (Aggregate crushing and aggregate impact values), particularly when compared with the results of sample \#17. In addition, limestone sample \#17 contains abundant stylolites and matrix support fabric which may make a poor aggregate (Plate 2). Stylolites are irregular, suture-like contacts produced by differential 
vertical movement under pressure in the presence of solution. They are marked by irregular and interlocking penetration on two sides (plate 2): Columns, pits and tooth-like projections on one side fit into their counterparts on the other side (Erik, 2010). The samples which have stylolites tend to have relatively lower compressive strength (Average value $=81 \mathrm{Mpa}$ ) when compared to the stylolites free samples (average value $=86 \mathrm{Mpa}$ ).

On top of this, in sample \#86 though there's some clastic quartz, however the Fe-minerals in this sample show oxidation (plate 6). Thus, due to intense oxidation, it shows poor (lowest) strength and aggregate quality as compared to sample \#28 (Table 12). But sample \#28 (plate 5 ) has the very best unconfined compressive strength and comparatively lowest AIV and ACV; indicating better rock strength and aggregate quality (AIV and ACV) (Table 12). The good quality may be due to well-cemented grains, the sharpness of grain corners or irregular shape, grain supported fabrics (plate 5), as well as fossils, are filled with larger crystals (coarse) sparitic calcite. The grain-support fabric, are indicated by a little or no mud, close packing of grains, and abundance of carbonate cement in interparticle pores. In plate (8) for instance, the bio-clasts are suspended within the lime mud. Thus, matrix-supported fabric alongside the pressure solution and oxidation contributes to the poor quality of the sample. This means that the knowledge of the petrographic features of rocks is of great importance for the estimation of their engineering behavior.

Generally, materials such as chalcedony, opal, volcanic glass filling vesicles, chert (often associated with limestone), zeolites, olivine, sulfides, and sulfates are undesirable and rocks containing them in concentrations greater than 0.5 to $1.0 \%$, should not be used as aggregates (Blyth \& Freiats, 1984). Thus, based on Petrographic examination, sample \#84, 90,63, and 24 contain dolomite crystals above $60 \%$ and are potentially susceptible to alkali-carbonate reaction. Moreover, sample \#2, and 29 contain chalcedony (from thin section analysis) above 1\%. Therefore, they are not suitable for aggregate. However, sulfates (from the XRF test) though present, is a trace in amount or less than $1 \%$ in all samples (Table 3 ).

The limestone samples have a very similar chemical composition and differences in the content of major elements are insignificant (Table 3). $\mathrm{MgO}$, Sio ${ }_{2}$, $\mathrm{Al}_{2} \mathrm{O}_{3}, \mathrm{Fe}_{2} \mathrm{O}_{3}$, and $\mathrm{SO}_{3}$ are also common mineral impurities that occurred in limestones. Kayaba, Soypak, \& Göz, (2018) suggested an equation Eq. (1) about the calculation of chemical homogeneity of the limestone and they stated that if the chemical homogeneity of limestone is greater than $>95$, the limestone is homogenous.

Chemical homogeneity $=100-\left[\% \mathrm{SiO}_{2}+\% \mathrm{Al}_{2} \mathrm{O}_{3}+\% \mathrm{Fe}_{2} \mathrm{O}_{3}+\mathrm{SO}_{3}\right]$ (eq.5)

According to (eq.5) the limestones of Harer-Dire Dawa areas are homogeneous limestone except for sample no $48,84,40,71,37,50,86$ which has chemical homogeneity $<95 \%$ (Table 3). The results of the XRF analysis show four metal oxides $\left.\left(\mathrm{Fe}_{2} \mathrm{O}_{3}, \mathrm{MgO}, \mathrm{CaO} \text {, and } \mathrm{SiO}\right)_{2}\right)$ that dominate the rock sample in the study area. The XRF analysis of samples from Harer-Dire Dawa revealed an average value of $\mathrm{CaO}$ of $49.23 \%$ with average levels of MgO $1.71 \%$. Calcium oxide (CaO) is the most dominant oxides in all samples of the study area but Silica $\left(\mathrm{SiO}_{2}\right)$ is the next dominant. Magnesium oxide (MgO) has the highest levels found in samples number 71 and 86 . Silicates $\left(\mathrm{SiO}_{2}\right)$ have the highest levels at samples $\# 84,48,40,71,37,50$, and 67 . If the $\mathrm{Al}_{2} \mathrm{O}_{3}$ content is too high, then the aggregate is deemed poor quality (Harris \& Chowdhury, 2007). In the current study, this correlation is in good agreement particularly for some engineering properties such as effective porosity and AIV. However, in the current study, the researchers speculate that clay mineralogy may be the most important factor in controlling aggregate durability.

Table 3. Chemical composition of Harer-Dire Dawa limestones 


\begin{tabular}{|c|c|c|c|c|c|c|c|c|c|c|c|c|}
\hline \multicolumn{6}{|c|}{ Identification: Chemical Composition of Limestone } & \multicolumn{5}{|c|}{ Test type: Complete silicate and sulfate analysis } & \multicolumn{2}{|c|}{ Rock Type: Limestone } \\
\hline \multicolumn{6}{|c|}{ No of Samples: 37} & \multicolumn{5}{|c|}{ Test method: ES 1172:2 Equivalent to EN 196:2 } & \multicolumn{2}{|c|}{ Source: Harer-Dire Dawa Area } \\
\hline S.N & Code & LOI & $\mathrm{SiO}_{2}$ & $\mathrm{Al}_{2} \mathrm{O}_{3}$ & $\mathrm{Fe}_{2} \mathrm{O}_{3}$ & $\mathrm{CaO}$ & $\mathrm{MgO}$ & $\mathrm{SO}_{3}$ & Total Carbonates & Sum & Purity \% & Remark \\
\hline 1 & 7 & 43.30 & 1.94 & 0.40 & 0.03 & 50.87 & 0.48 & 0.13 & 92.06 & 97.15 & 97.50 & XRF \\
\hline 2 & 16 & 43.27 & 1.70 & 0.32 & 0.08 & 51.77 & 0.13 & 0.08 & 92.79 & 97.35 & 97.82 & XRF \\
\hline 3 & 48 & 42.19 & 4.47 & 1.23 & 0.87 & 40.38 & 8.80 & 0.07 & 93.95 & 98.01 & 93.36 & XRF \\
\hline 4 & 72 & 43.32 & 1.84 & 0.43 & 0.16 & 50.05 & 1.60 & 0.09 & 93.36 & 97.49 & 97.48 & XRF \\
\hline 5 & 77 & 43.52 & 2.66 & 0.56 & 0.32 & 49.80 & 0.45 & 0.09 & 90.04 & 97.40 & 96.37 & XRF \\
\hline 6 & 84 & 37.91 & 9.49 & 2.53 & 1.49 & 43.00 & 0.28 & 0.06 & 77.49 & 94.76 & 86.43 & XRF \\
\hline 7 & 60 & 43.45 & 3.08 & 0.53 & 0.63 & 49.49 & 0.78 & 0.11 & 90.31 & 98.07 & 95.65 & XRF \\
\hline 8 & 17 & 43.24 & 2.37 & 0.77 & 0.34 & 52.50 & 0.12 & 0.22 & 93.91 & 99.56 & 96.30 & Chemical \\
\hline 9 & 42 & 43.05 & 2.71 & 0.49 & 0.18 & 52.41 & 0.36 & 0.18 & 94.25 & 99.38 & 96.44 & Chemical \\
\hline 10 & 2 & 42.47 & 2.59 & 0.45 & 0.14 & 50.28 & 0.38 & 0.09 & 90.73 & 96.40 & 96.73 & XRF \\
\hline 11 & 4 & 43.33 & 1.40 & 0.28 & 0.01 & 51.47 & 0.44 & 0.10 & 93.02 & 97.03 & 98.21 & XRF \\
\hline 12 & 13 & 43.30 & 1.42 & 0.18 & 0.01 & 51.95 & 0.31 & 0.09 & 93.56 & 97.26 & 98.30 & XRF \\
\hline 13 & 28 & 42.11 & 3.32 & 0.64 & 0.29 & 49.36 & 0.70 & 0.09 & 89.91 & 96.51 & 95.66 & XRF \\
\hline 14 & 40 & 41.66 & 4.93 & 0.92 & 0.55 & 47.64 & 0.73 & 0.10 & 86.89 & 96.53 & 93.50 & XRF \\
\hline 15 & 51 & 43.10 & 1.26 & 0.31 & 0.30 & 51.51 & 0.13 & 0.08 & 92.32 & 96.69 & 98.05 & XRF \\
\hline 16 & 71 & 43.55 & 4.06 & 1.32 & 1.07 & 32.60 & 15.62 & 0.08 & 96.97 & 98.30 & 93.47 & XRF \\
\hline 17 & 19 & 43.26 & 2.40 & 0.57 & 0.10 & 49.03 & 1.73 & 0.10 & 91.87 & 97.19 & 96.83 & XRF \\
\hline 18 & 47 & 42.57 & 3.04 & 0.70 & 0.24 & 52.29 & 0.51 & 0.14 & 94.35 & 99.49 & 95.88 & Chemical \\
\hline 19 & 70 & 42.82 & 2.93 & 0.49 & 0.24 & 52.54 & 0.32 & 0.15 & 94.40 & 99.49 & 96.19 & Chemical \\
\hline 20 & 25 & 42.32 & 1.46 & 0.37 & 0.13 & 51.33 & 0.51 & 0.08 & 92.95 & 96.2 & 97.96 & XRF \\
\hline 21 & 37 & 40.25 & 4.71 & 0.62 & 0.65 & 48.32 & 0.36 & 0.08 & 87.20 & 94.99 & 93.94 & XRF \\
\hline 22 & 50 & 42.08 & 4.68 & 0.93 & 0.54 & 43.79 & 5.5 & 0.10 & 91.85 & 97.62 & 93.75 & XRF \\
\hline 23 & 63 & 41.75 & 3.06 & 0.81 & 0.38 & 49.92 & 0.52 & 0.07 & 90.43 & 96.51 & 95.68 & XRF \\
\hline 24 & 67 & 41.09 & 4.32 & 0.37 & 0.09 & 49.46 & 0.48 & 0.11 & 89.53 & 95.92 & 95.11 & XRF \\
\hline 25 & 86 & 40.99 & 3.89 & 0.8 & 0.56 & 32.96 & 15.6 & 0.09 & 97.57 & 94.89 & 94.66 & XRF \\
\hline 26 & 99 & 42.67 & 1.47 & 0.33 & 0.02 & 51.82 & 0.38 & 0.09 & 93.49 & 96.78 & 98.09 & XRF \\
\hline 27 & 82 & 42.83 & 2.93 & 0.42 & 0.42 & 52.38 & 0.3 & 0.14 & 94.07 & 99.42 & 96.09 & Chemical \\
\hline 28 & 32 & 42.15 & 2.58 & 0.57 & 0.24 & 49.63 & 0.42 & 0.15 & 89.42 & 95.74 & 96.46 & Chemical \\
\hline 29 & 49 & 43.57 & 1.91 & 0.53 & 0.24 & 50.48 & 2.36 & 0.05 & 94.99 & 99.14 & 97.27 & Chemical \\
\hline 30 & 90 & 43.18 & 1.69 & 0.26 & 0.12 & 53.78 & 0.36 & 0.09 & 96.70 & 99.48 & 97.84 & Chemical \\
\hline 31 & 10 & 42.68 & 2.68 & 0.48 & 0.11 & 49.81 & 0.62 & 0.11 & 90.50 & 96.49 & 96.62 & XRF \\
\hline 32 & 24 & 42.84 & 1.71 & 0.43 & 0.32 & 51.03 & 0.39 & 0.08 & 92.12 & 96.80 & 97.46 & XRF \\
\hline 33 & 29 & 42.61 & 2.60 & 0.40 & 0.16 & 50.47 & 0.48 & 0.11 & 91.32 & 96.83 & 96.73 & XRF \\
\hline 34 & 46 & 42.39 & 2.29 & 0.53 & 0.29 & 50.53 & 0.46 & 0.12 & 91.39 & 96.61 & 96.77 & XRF \\
\hline 35 & 78 & 43.05 & 1.12 & 0.22 & 0.01 & 52.19 & 0.16 & 0.08 & 93.61 & 96.83 & 98.57 & XRF \\
\hline 36 & 58 & 42.14 & 1.96 & 0.53 & 0.48 & 52.07 & 0.24 & 0.12 & 93.39 & 97.54 & 96.91 & Chemical \\
\hline 37 & 34 & 41.24 & 2.93 & 0.68 & 0.24 & 52.75 & 0.36 & 0.29 & 94.86 & 98.49 & 95.86 & Chemical \\
\hline Mean & & 42.47 & 2.85 & 0.61 & 0.33 & 49.23 & 1.71 & 0.11 & 92.10 & 97.31 & 96.11 & \\
\hline
\end{tabular}

In limestone, porosities change with increasing age and/or burial depth of the sediment (Erik, 2010). As a result, some samples such as \#90, 84, 2, 60, 71, 47, 59,13 , and 86 are collected stratigraphically from a higher elevation, which is younger than all the rest obtained from relatively lower stratigraphic sections. 
This age difference is a good indicator of limestone quality. The younger rock typically is more poorly cemented and softer, resulting in less durable aggregate (Harris \& Chowdhury, 2007).

\section{Conclusion}

From the achieved results, it could be concluded that there are certain limestones with chemical, physical, and strength properties that are adequate for serving as construction materials for highway pavements. This observation is based on the laboratory-obtained strength and mineralogical properties of these limestones.

The strength is mainly dependent on the presence of rifting since both minimum and maximum values are from the same group. Moreover, significantly different values were obtained for the same samples indicating the effect of rifting. When compared with the maximum permissible limits of standards the measured values of AIV for all varieties of limestone complies with standards values for pavement applications. All samples of dolomitized bio oosparry limestone are excellent for pavement base course. However, the same limestone type was evaluated as good for pavement surfacing course. Siliceous bio pel micritic limestone is also excellent for pavement works. Almost all samples collected except sample \#86, 13, and 71 are evaluated as excellent for pavement base course. Under hot weather conditions, frequent contact of the limestone base-course materials with water may cause weathering of these materials (sample \#86) and thus have a deleterious effect on the durability and serviceability of highway pavements. In general, the absorption results of the Harer-Dire Dawa limestone showed a very low absorption value and considered advantageous.

Aggregates of Harer-Dire Dawa limestone are more resistant to sudden impact (tough) and fragmentation by abrasion than a continuous gradual load. The average value of the fragmentation resistance (LAAV) and ACV were $=23.3$ and 29.3 , respectively, whereas the average value of the impact resistance (AIV) was $=13.2$. Therefore, it can be concluded that the Harer-Dire Dawa limestone aggregates will be better suited for the construction of elements subjected to dynamic loads.

In this study, all samples except a sample with the maximum value (\#86) satisfy the maximum percentage losses of $\mathrm{Na}_{2} \mathrm{So}_{4}$ soundness requirement (10\%-fine aggregates and $12 \%$-coarse aggregates) for crushed stone unbound road base course, and bituminous bound surfacing or wearing course.

Dolomitic limestones are generally preferred in asphaltic concrete wearing courses since they are generally harder and tend to polish less, thus maintaining their skid-resistance properties longer. Dolomitic limestones also have lower absorption rates and thus lead to the use of lower Bitumen Content in asphaltic concrete mixes.

Last but not least, locally available limestone, although variable in quality and physical properties, can be used in road construction applications by appropriate mining and processing where igneous source aggregate has previously been used. However, the aggregates to be used in road construction, particularly in the wearing course of the pavement should be sufficiently resistant to crushing to withstand the high stresses induced due to heavy traffic wheel loads.

The mechanical properties of the rock are greatly influenced by the composition, fabric (arrangement of intraclasts of skeletons and voids), and the diagenetic processes. Especially Stylolites are the product of intergranular pressures-solution and are pervasive in the studied limestone. The prevalent views are that the presence of stylolites significantly weakens rocks and that they induce a significant mechanical anisotropy. Therefore, the impact of stylolite on strength of limestone can't be neglected in geotechnical applications, even if the stylolites are closed.

Generally, the results indicate that rocks of the same type in different areas have different physical and mechanical values. This is because of the difference in the geological setting and other physical properties. Thus it can be concluded that changes in texture and mineralogical characteristics due to crystallization, diagenesis, and tectonism appear to affect the engineering properties of the same rocks in different areas.

\section{Declarations}

Plates 1-8 are available in the Supplementary Files

\section{Acknowledgements}

The authors are thankful for everyone's supports provided by AASTU and ASTU. We would like to acknowledge Mr. Belachew Moges from AASTU, Mr. Moika Dinsa, Mr. Abity Takle, Mr. Abiot Tesfaye, Mr. Mesele, and Mr. Debele Bari from ASTU for the technical support and assistance during lab work.

\section{Competing Interests}

The authors declare no competing interests.

\section{References}

AASHTO T 96-94. (1994). Standard Method of Test for Resistance to Degradation of Small-Size Coarse Aggregate by Abrasion and Impact in the Los Angeles Machine. Annual Book of AASHTO Standards.

Abate, E. Y. (2010). Anthropogenic Impacts on Groundwater Resources in the urban Environment of Dire Dawa, Ethiopia. MSc Thesis in Geosciences, University of Oslo, pp160. 
Adeyi, O. G., Mbagwu, C. C., Ndupu, C. N., \& Okeke, C. O. (2019). Production and Uses of Crushed Rock Aggregates. International Journal of Advanced Academic Research, 5(8), 92-110.

Alqahtani, M. B., Seif, A., \& Sedek, E. S. (2013). Correlations between petrography and some engineering properties of coralline limestone: A case study along the Red Sea Coast of Jeddah, Saudi Arabia. Journal of King Abdulaziz University, Earth Sciences, 24(1), 99-114. https://doi.org/10.4197/Ear.24-1.6

Aragaw, H. (2008). Evaluation of the Suitability of Basaltic Rock as Source of Concrete Aggregate in and around Addis Ababa City. MSc Thesis, Addis Ababa University, PP78.

ASTM C131-96. (1996). Standard Test Method for Resistance to Degradation of Large-Size Coarse Aggregate by Abrasion and Impact in the Los Angeles Machine. Annual Book of ASTM Standards.

ASTM C170-90. (1999). Standard Test Method for Compressive Strength of Dimension Stone. Annual Book of ASTM Standards, (Reapproved).

ASTM C88-99a. (1999). The soundness of Aggregates by Use of Sodium Sulfate or Magnesium Sulfate. Annual Book of ASTM Standards.

ASTM D2845. (2000). Standard Test Method for Laboratory Determination of Pulse Velocities and Ultrasonic Elastic Constants of Rock. Annual Book of ASTM Standards, pp7.

Balemwal, A. (1991). Stratigraphy and Carbonate Microfacies of the Hirna Mesozoic sequence. MSc Thesis, Addis Ababa University, pp79.

Blyth, F. G. ., \& Freiats, M. H. d. (1984). A Geology for Engineers. CRC Press, London, p349.

Bosellini, A., Russo, A., and, \& Assefa, G. (2001). The Mesozoic succession of Dire Dawa, Harar Province, Ethiopia. Journal of African Earth Sciences, 32(3), 403-417.

Brilli, M., Giustini, F., \& Kadıoğlu, M. (2018). Black Limestone Used in Antiquity: Recognizing the Limestone of Teos. University of Oxford, Archaeometry, 1-14.

BS-EN-1926. (2006). Natural-Stone-Test-Methods-Uniaxial-Compressive-Strength. Annual Book of BS Standards., p18.

BS 812-105.2. (1990). Testing aggregates-Methods for determination of particle shape-Section 105.2 Elongation index of coarse aggregate. Annual Book of BS Standards.

BS 812-110. (1990). Testing aggregates-Part 110: Methods for determination of aggregate crushing value (ACV). Annual Book of BS Standards.

BS812-105.1. (1989). Testing aggregates-Methods for determination of particle shape-Section 105.1 Flakiness index. Annual Book of BS Standards.

BS812-112. (1990). Testing aggregates-Part 112: Methods for determination of aggregate impact value (AIV). Annual Book of BS Standards.

Dunham, R. J. (1962). Classification of carbonate rocks according to depositional texture. American Association Petroleum Geologists Memoirs (1), $108-121$.

Dweirj, M., Fraige, F., Alnawafleh, H., \& Titi, A. (2017). Geotechnical Characterization of Jordanian Limestone. Geomaterials, 07(01), 1-12.

https://doi.org/10.4236/gm.2017.71001

Engidasew, T. A., \& Barbieri, G. (2014). Geo-engineering evaluation of Termaber basalt rock mass for crushed stone aggregate and building stone from Central Ethiopia. Journal of African Earth Sciences, 99, 581-594.

Erik, F. (2010). Microfacies of Carbonate Rocks: Analysis, Interpretation, and Application. pp1006.

Ethiopian Roads Authority Standard Technical Specification (ERA-STS). (2002). Flexible Pavements and Gravel Roads. Pavement Design Manual, I.

Folk, R. L. (1962). Spectral subdivision of limestone types, classification of carbonate rocks. Symp Am Assoc Petrol Geol, 62-8.

Harris, J. P., \& Chowdhury, A. (2007). Tests to Identify Poor Quality Coarse Limestone Aggregates and Acceptable Limits for Such Aggregates in Bituminous Mixes. Technical Report 0-4523-2, pp118.

Jamaluddin, Darwis, A., \& Massinai, M. A. (2018). X-Ray Fluorescence ( XRF ) to identify the chemical analysis of minerals in Buton island, SE Sulawesi, Indonesia. IOP Conference Series: Earth and Environmental Science, 118 012070, 1-5. https://doi.org/10.1088/1755-1315/118/1/012070

Jethro, M. A., Shehu, S. A., \& Olaleye, B. M. (2014). The Suitability of Some Selected Granite Deposits for Aggregate Stone Production in Road Construction. The International Journal Of Engineering And Science (IJES), 3(2), 75-81.

Kayabaşı, A., Soypak, R., \& Göz, E. (2018). Evaluation of limestone quarries for concrete and asphalt production: a case study from Ankara, Turkey. Arabian Journal of Geosciences, 11(20), 1-22. https://doi.org/10.1007/s12517-018-3990-8

Ketema, T. (1982). Geological Investigations for the Construction of A drift for A Dynamite store in the Dire Dawa Area. Ethiopian Institute of Geological Survey, Note No 176, pp18. 
Kibrie, T., \& Yirga, T. (2008). The Geology of Bedesa Area (NC37-16). Geological Survey of Ethiopia, Basic Geoscience Mapping Core Process, Memoir No. 19, pp138.

Nata, T., Bheemalingeswara, K., \& Abdulaziz, M. (2010). Hydrogeological Investigation and Groundwater Potential Assessment in Haromaya Watershed, Eastern Ethiopia. MEJS, CNCS-Mekelle University, 2(1), 26-48.

Okogbue, C. O., \& Aghamelu, O. P. (2013). Performance of pyroclastic rocks from Abakaliki Metropolis (southeastern Nigeria) in road construction projects. Bull Eng Geol Environ, 72, 433-446. https://doi.org/10.1007/s10064-013-0489-0

Singh, B., \& Goel, R. K. (2011). Engineering Rock Mass Classification: Tunneling, Foundations, and Landslides. Elsevier Inc. United States of America, pp382.

Tesfaye, A. E., \& Asmelash, A. (2016). Assessment and Evaluation of Volcanic Rocks Used as Construction Materials in the City of Addis Ababa. Momona Ethiopian Journal of Science (MEJS), 8(2), 193-212. https://doi.org/10.4314/mejs.v8i2.7

Tilahun, K., \& Merkel, B. J. (2009). Estimation of groundwater recharge using a GIS-based distributed water balance model in Dire Dawa, Ethiopia. Water, 1443-1457. https://doi.org/10.1007/s10040-009-0455-x

Walle, H., Zewde, S., \& Heldal, T. (2000). Building stone of central and southern Ethiopia: deposits and resource potential. Norges Geologiske Undersøkelse Bulletin 436, N-7491 Trondheim, Norway, 175-182.

Wondafrash, M., Sentayehu, Z., \& Geremew, N. (2009). Investment Opportunities in Limestone Resources Development of Ethiopia. Promotion Document, Geological Survey of Ethiopia (GSE), pp13.

Workineh, H. (2010). Geology of the Harer Areas (NC 38/9). Geological Survey of Ethiopia, Basic Geoscience Mapping Core Process, Memoir No. 21 , pp124. Wright, V. P. (1992). A revised classification of limestones. Sedimentary Geology, 76, 177-185.

Yirga, M., Weldearegay, K., \& Abebe, T. (2017). Evaluation of Suitability of Coarse Aggregate for Concrete in Mekele Area, Ethiopia. International Journal of Scientific \& Engineering Research, 8(10), 1235-1240.

\section{Figures}




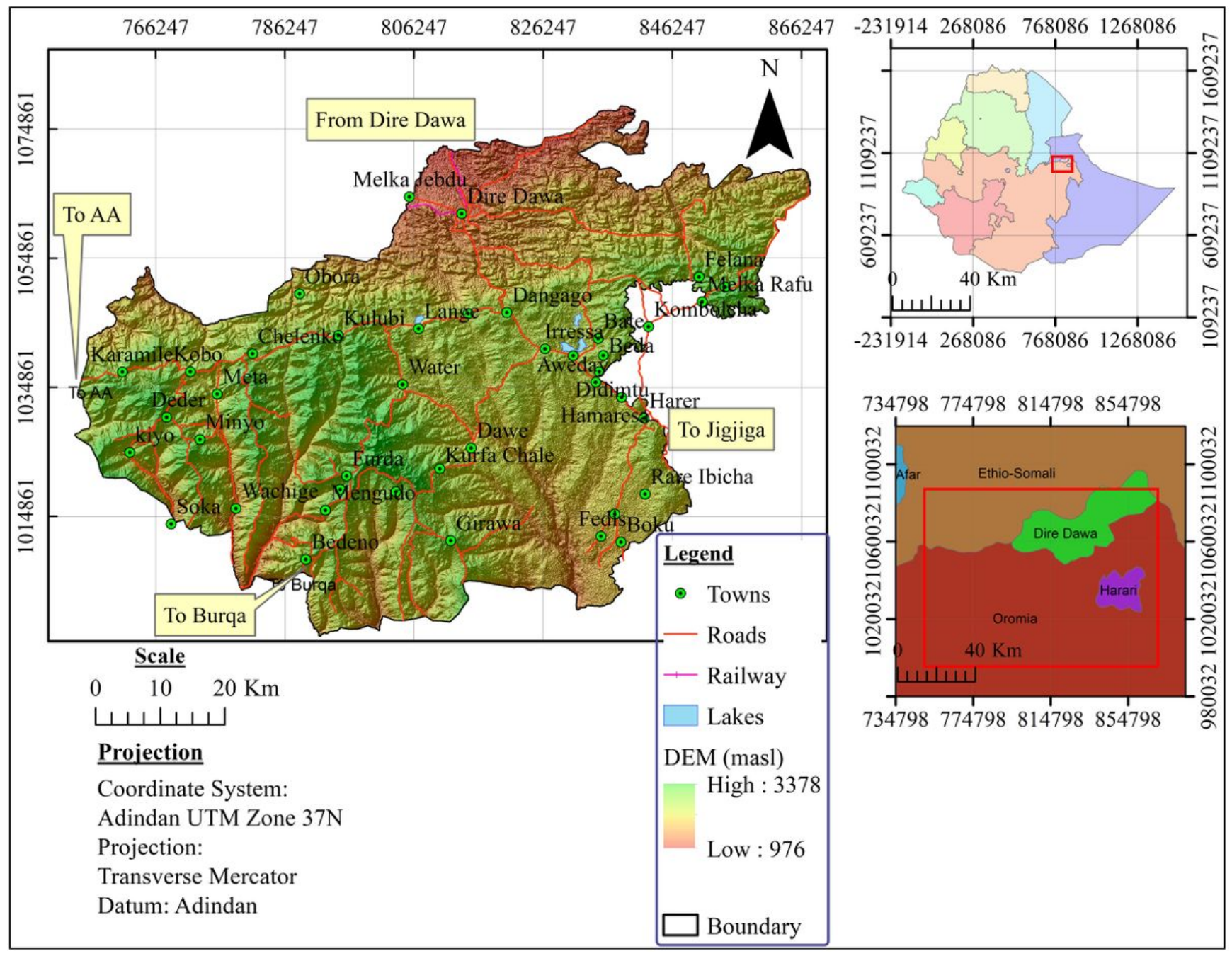

Figure 1

Location map of the study area. 


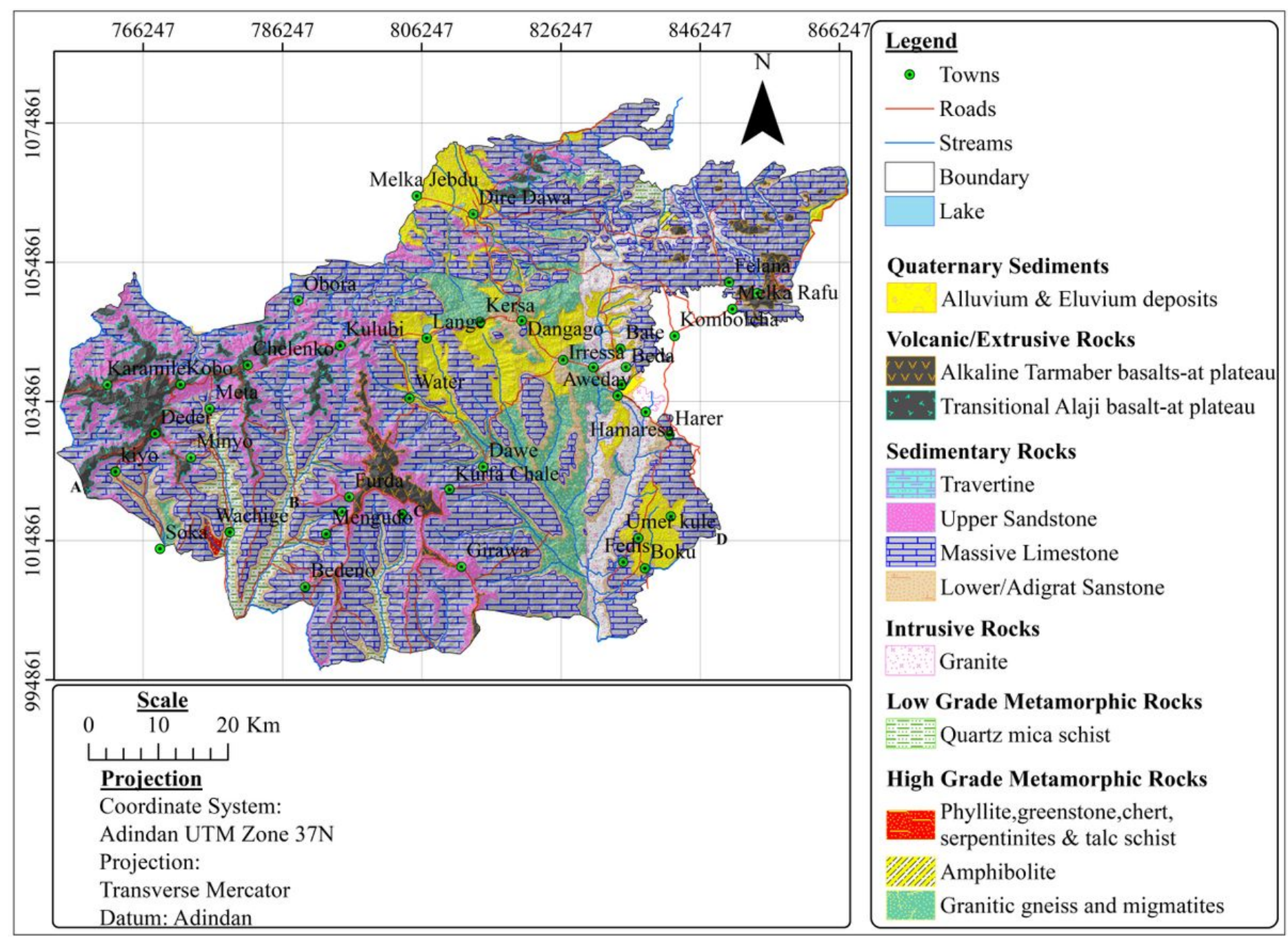

Figure 2

Geological map of the study area. 


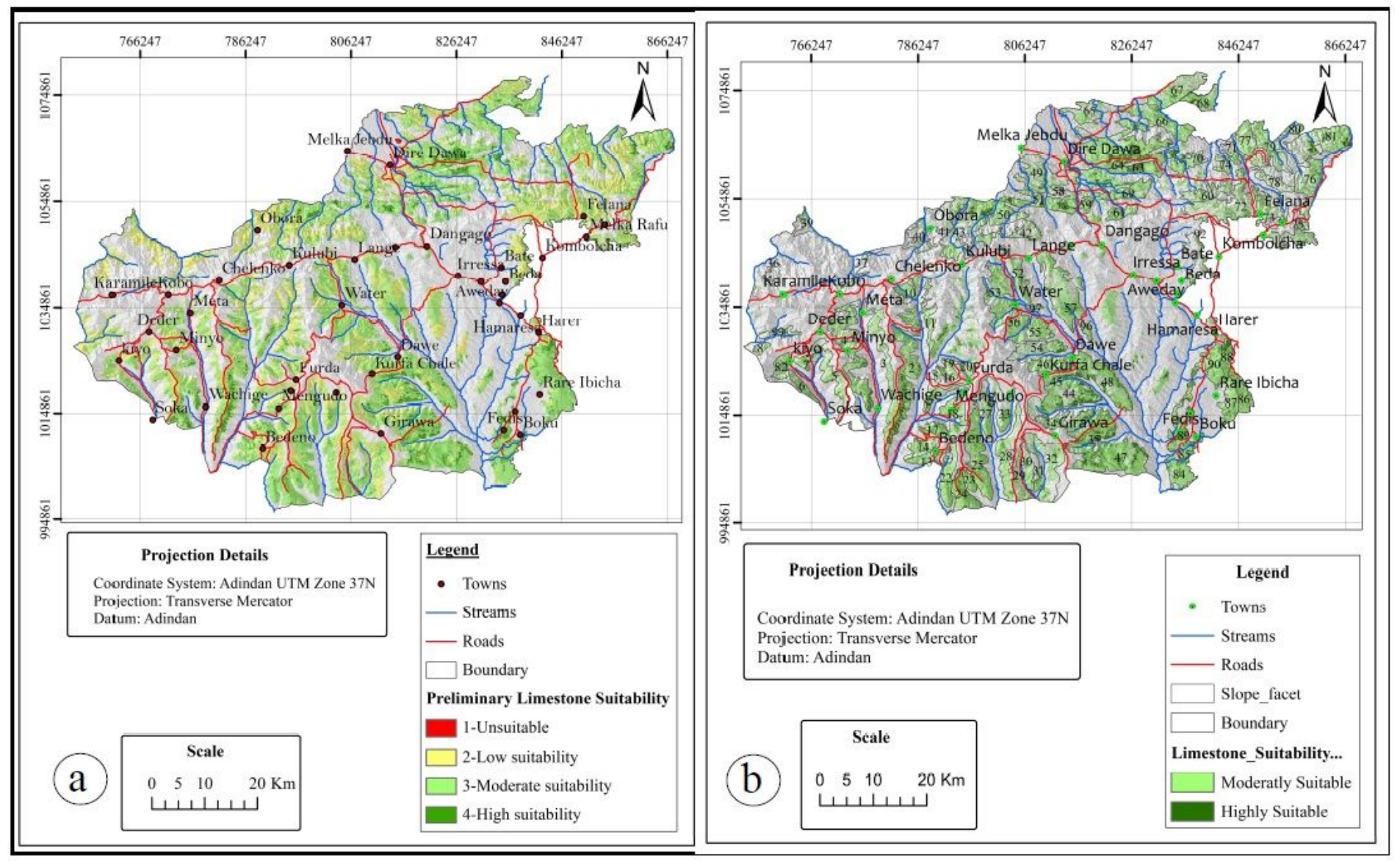

Figure 3

(a) Preliminary quarry site suitability map for all quarry sites in the study area; b) Suitability map for limestone quarry sites in the study area. 


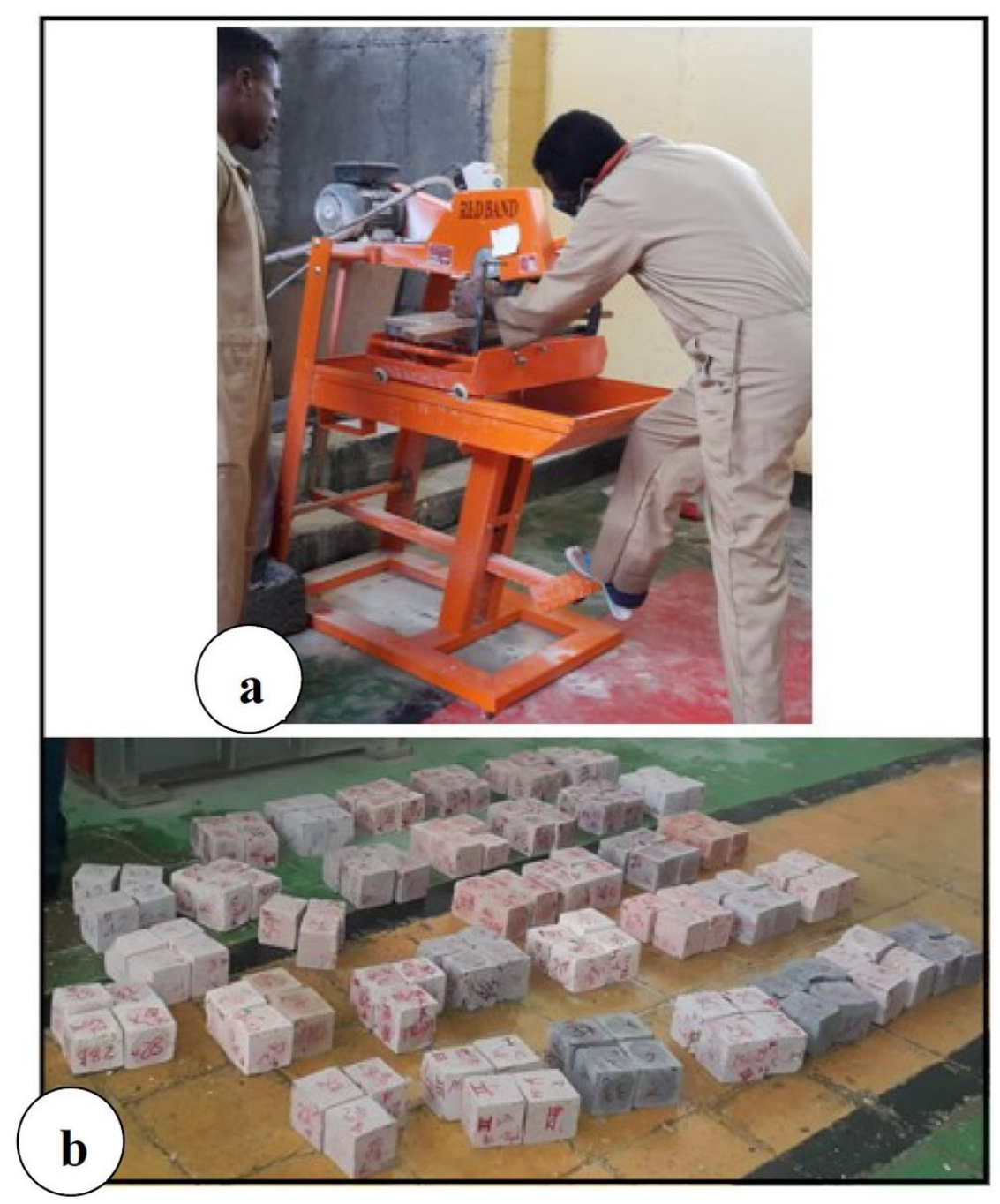

Figure 4

a) Red Band Masonry Saw for rock Cube preparation; b) Rock Cubic Specimens.

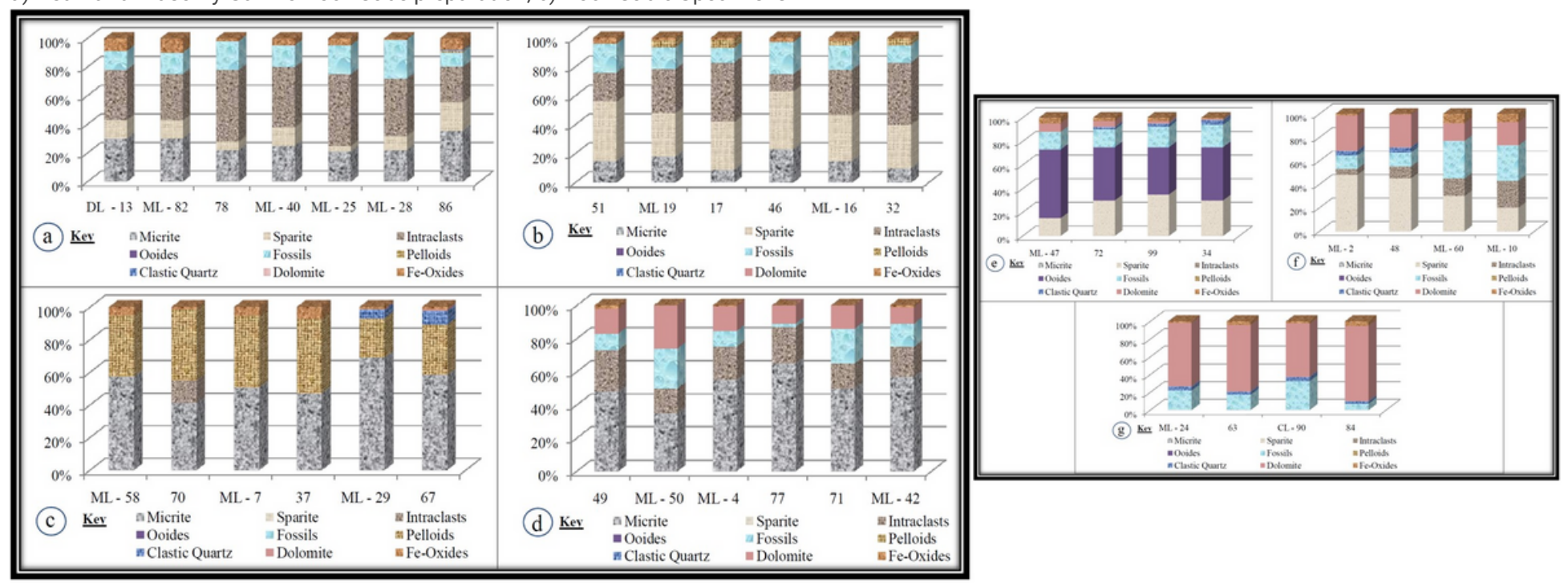

\section{Figure 5}

Modal Composition of Rocks Studied by Thin Sections Analysis (a) for biointramicritic limestone (b) for biointraspary limestone (c) for biopelmicritic limestone (d) for dolomitized biointramicritic limestone (e) for dolomitized biooospary limestone (f) for dolomitized biointraspary limestone (g) for calcareous dolomite. 


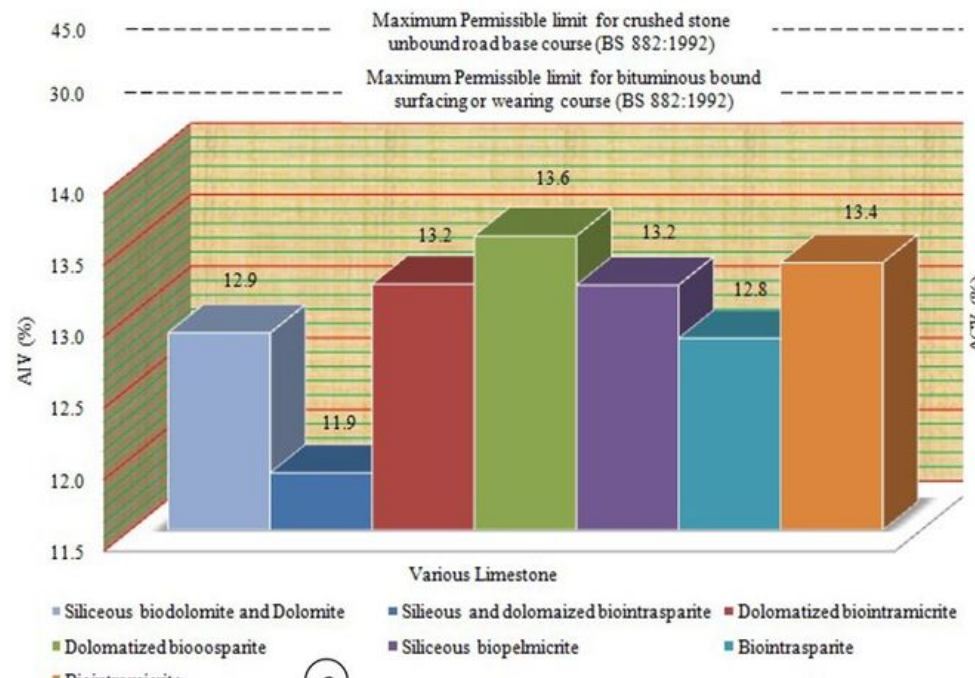

= Dolomatized biooosparite

- Biointramicrite (a)

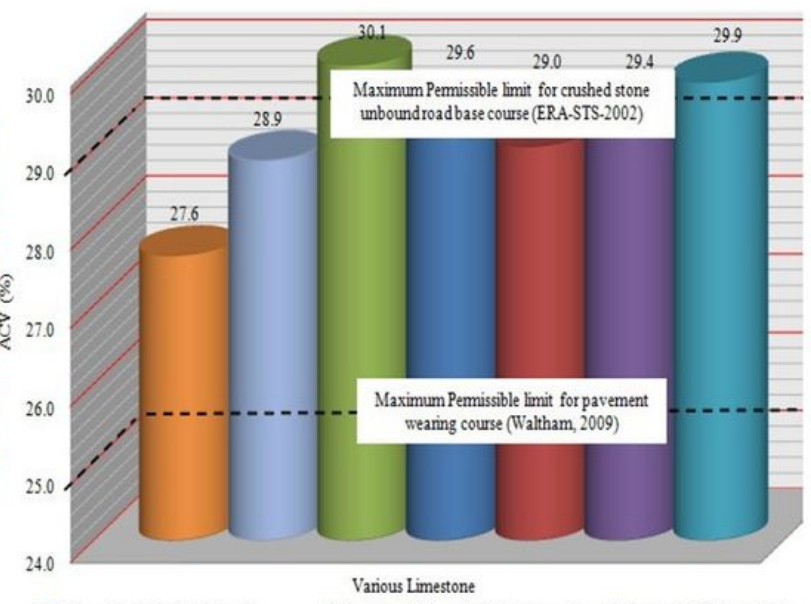

aSiliceous biodolomite-Dolomite -Dolomatized biooospante - Biointramicrite (b) घBiointraspante
Various Limestone
॥Silieous and dolomaized biointrasp ante $₫$ Dolomatized biointramicrite

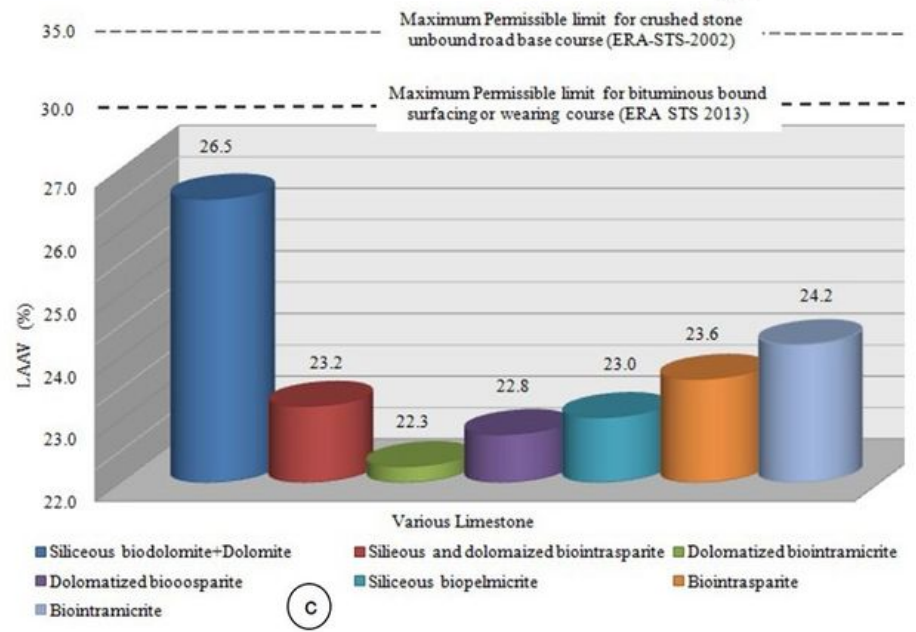

\section{Figure 6}

Bar chart showing the comparisons of a) AIV b) ACV c) LAAV for various limestones and comparison against standards.

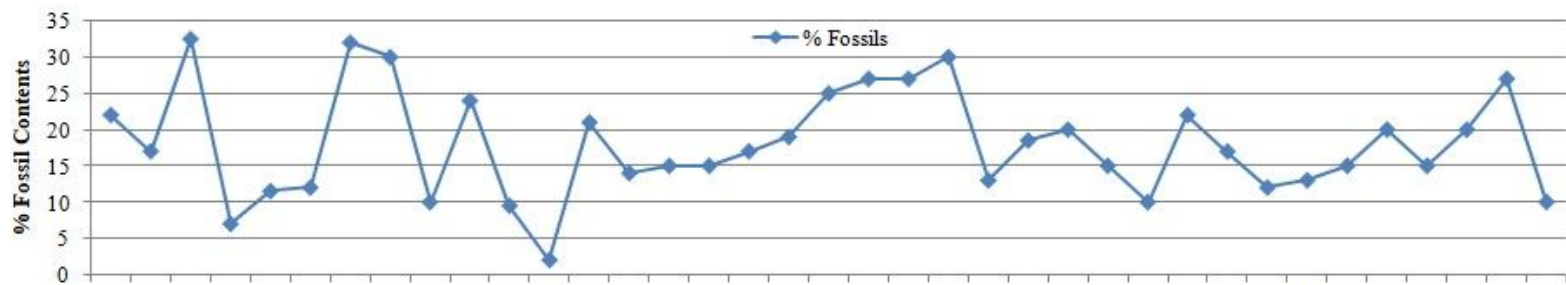

$\begin{array}{lllllllllllllllllllllllllllllllllllll}24 & 63 & 90 & 84 & 2 & 48 & 60 & 10 & 49 & 50 & 4 & 77 & 71 & 42 & 47 & 72 & 99 & 34 & 58 & 70 & 7 & 37 & 29 & 67 & 51 & 19 & 17 & 46 & 16 & 32 & 13 & 82 & 78 & 40 & 25 & 28 & 86\end{array}$

Sample \#

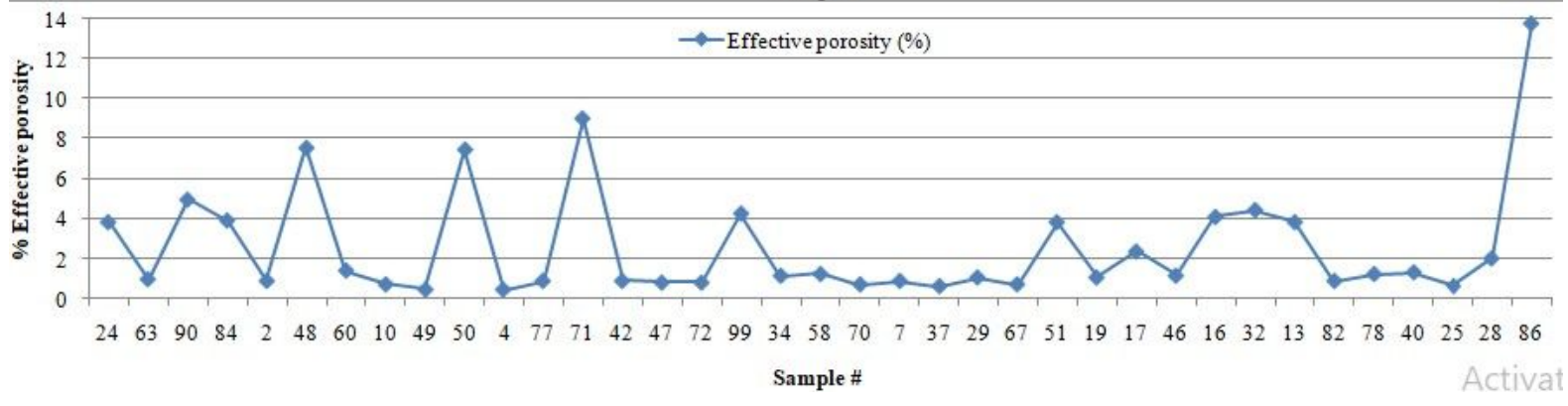

Figure 7

Comparision of the percentages of bioclasts with effective porosity. 
This is a list of supplementary files associated with this preprint. Click to download.

- Fig.812.jpg

- Fig.834.jpg

- Fig.856.jpg

- Fig.878.jpg 